\title{
Patatin-like PLA2 with cytotoxicity against mammalian and plant tumour cells
}

\author{
Bernard Griffaut ${ }^{1}$, Eric Debiton ${ }^{2,3}$, Marie-Josèphe Galmier ${ }^{2,3}$, Ana Mustel ${ }^{1,2}$, \\ Jean-Claude Madelmont ${ }^{2,3}$, Gérard Ledoigt ${ }^{1^{*}}$ \\ ${ }^{1}$ Clermont Université, UMR 547 INRA-Université PIAF, Université Blaise-Pascal, Campus des Cézeaux, Aubière Cedex, France \\ ${ }^{2}$ Clermont Université, Université d'Auvergne, Imagerie Moléculaire et Thérapie Vectorisée, BP, Clermont-Ferrand, France \\ ${ }^{3}$ Inserm, UMR 990, IMTV, Clermont-Ferrand, France \\ Email: " gerard.ledoigt@,univ-bpclermont.fr
}

Received 3 August 2013; revised 5 September 2013; accepted 18 September 2013

Copyright (C) 2013 Bernard Griffaut et al. This is an open access article distributed under the Creative Commons Attribution License, which permits unrestricted use, distribution, and reproduction in any medium, provided the original work is properly cited.

\begin{abstract}
Plants can respond to traumatism by synthesis and secretion of defence molecules. Wound-healing and desiccation stress of pieces of potato tuber parenchyma (Solanum tuberosum) promoted the secretion of a patatin-like phospholipase $A_{2}, P L A_{2}$ (EC.3.1.1.4.) that displayed cytotoxic activity against tumour cells. The potato secretion product, an oligomeric form of patatin-like protein, was shown to contain several isoforms of $\mathrm{PLA}_{2}$ polypeptides and to be associated with other proteins, including Kunitz-type protease inhibitors. Patatin-like protein secretion was inhibited by vanadate. Secreted patatin-like proteins displayed specific features, such as extracellular function and low molecular weights, mainly 36 to $40 \mathrm{kDa}$. The 36-kDa polypeptide sequence was related to $\mathrm{iPLA}_{2} \alpha$. Polypeptide spots of secreted patatin-like protein exhibited a nucleotide-binding consensus motif, GGGIKG that has been described in iPLA 2 gene family. The cytotoxic agent caused cell death of plant crown-gall induced by Agrobacterium tumefaciens, and inhibited B16 cell proliferation, but at the same concentration did not display any toxicity against non-transformed cells. PLA $_{2}$ enzyme activity was required for cytotoxicity against B16 melanoma cells. A model for such a specific activity against tumour cells is discussed in connection with asymmetric phospholipid patterns of cell membranes. In conclusion, secreted patatin-like $\mathbf{P L A}_{2}$ (e-patatin) may represent a novel therapeutic target for the development of new agents against cancer.
\end{abstract}

Keywords: Cancer; Cytotoxicity; Patatin; Phospholipase $\mathrm{A}_{2}$

*Corresponding author.

\section{INTRODUCTION}

In response to a stress, plants can synthesize and secrete a large variety of secondary metabolites. We have previously shown that a wound healing and desiccation of plant tubers promoted secretion of cytokinin-like products. At least one of these compounds, kinetin riboside, induced a cytotoxic effect both on plant and mammalian tumour cells [1]. In Jerusalem artichoke tubers (Helianthus tuberosus), after the same stimuli, we have shown secretion of a cytotoxic protein related to a superoxide dismutase [2]. This protein alone or possibly associated with a co-factor was shown to induce cytotoxicity in plant and animal tumour cells, preserving non-tumour cells in both cases. In potato (Solanum tuberosum), after such a stress condition, tuber parenchyma was shown to secrete new types of Kunitz-like protease inhibitors closely associated with another unknown polypeptide of approximately $40 \mathrm{kDa}$ [3].

Patatins are potato tuber proteins with acyl-hydrolyzing activity (LAH), and patatin catalytic domain is widely spread in bacterial, yeast, plant and animal enzymes. Recent results have indicated that patatin-related enzymes are involved in different cellular functions, including plant responses to auxin, elicitors or pathogens, and abiotic stresses and lipid mobilization during seed germination [4]. Individual types of patatin varying in their masses occur in patatin family in a ratio specific for each of the cultivars, with the lowest mass type being the major one. Patatin samples within most of cultivars exhibited high values of specific LAH activity. It may be supposed that individual patatin forms do not have similar physiological roles. These findings have supported the concept that patatin is not only a storage protein but could also be a part of potato defense mechanism [5].

Patatin glycoprotein is found associated with $\mathrm{Ku}-$ nitz-like protease inhibitors in mature potato tubers $[6,7]$. 
Patatin is a 42-kDa glycoprotein with various isoforms, which has been found in all Solanum species, with a precursor form containing a 23 amino-acid signal peptide [6,8-10]. In Solanum tuberosum, patatin is a multigene family with 10 to 18 members per haploid genome $[11,12]$. Patatin is now presumed to play an active role in plant signalling involving its lipid acyl hydrolase activity, related to the phospholipase $A_{2}[13,14]$. Indeed, it exhibits esterase activity in a broad range of lipid substrates [15]. Phospholipases $\mathrm{A}_{2} \mathrm{~S}$ are esterases that cleave glycerophospholipids at the $s n-2$ position, releasing a fatty acid, such as arachidonic acid, and a lysophospholipid that has been found to perform many important roles both in plants and animals [16-19]. A patatin-like phospholipase family was recently described in humans, which indicates that patatin or patatin-like peptides may have conserved an activity in cell signalling across both the animal and plant kingdoms [20]. Phospholipid degradation initiated by receptor stimulation produces various lipid mediators that relay information from extracellular signals to intracellular events [19]. In animals, $\mathrm{PLA}_{2}$ enzymes and their enzymatic products have been implicated in diverse cellular responses, including bioactive lipid production, inflammation, and signal transduction $[17,18]$. PLA 2 activities have also been implicated in cellular process in plants, such as growth, development, stress responses, and defence signalling [21].

Patatin domain-containing lipolytic enzymes, according to several authors, now comprise five subfamilies: plant patatin-related enzymes, animal calcium-independent enzymes ( $\left.\mathrm{iPLA}_{2} \alpha, \mathrm{iPLA}_{2} \beta, \mathrm{iPLA}_{2} \gamma\right)$, calciumactivated (cytosolic) cPLA $_{2}$ enzymes, neuropathy target esterases (NTEs) and desnutrin-related triglyceride hydrolases [4]. pPLA-II $\alpha$ is not only a signaling enzyme but can catalyze a late, non-specific hydrolysis of membrane lipids that commits tissues to cell death and affects differential resistance to pathogens. Members of the patatin LAH family can have opposite effects on pathogen resistance, possibly via distinct molecular mechanisms [22]. Growing evidence suggests that phospholipase $\mathrm{A}_{2}$ plays a pivotal role in tumorigenesis in human gastrointestinal cancer. One of the well-studied isoforms of $\mathrm{PLA}_{2}$, group IIA PLA PLA $\left._{2} \mathrm{G} 2 \mathrm{~A}\right)$ appears to exert its protumorigenic or antitumorigenic effects on a tissuespecific manner. $\mathrm{PLA}_{2} \mathrm{G} 2 \mathrm{~A}$ protein is an extracellular enzyme with a low molecular mass of $\sim 14 \mathrm{kd}$. Presence of $\mathrm{PLA}_{2} \mathrm{G} 2 \mathrm{~A}$ has been observed in a variety of human diseases including cancer [23].

In this work, we show that a patatin-like $\mathrm{PLA}_{2}$ was actively secreted from potato tuber parenchyma after cutting and water stress, and that protein is involved in cytotoxicity mainly against tumour cells in plants and animals.

\section{MATERIALS AND METHODS}

\subsection{Plant Materials}

Potato tubers (Solanum tuberosum L. cv agata) of commercial origin were used as source. Jerusalem artichoke tubers (Helianthus tuberosus L.) were grown in fields, harvested in autumn and stored at $4^{\circ} \mathrm{C}$ ( 3 months $)$ to relieve their dormancy. The crown-gall, a well-known model of plant tumours, was induced by Agrobacterium tumefaciens (strain B6 806) infection on pieces of Jerusalem artichoke tubers $(H$. tuberosus $\mathrm{L})$ cultured in Knop medium under controlled conditions $\left(25^{\circ} \mathrm{C}\right)$ as previously described [24]. This plant was chosen for its high susceptibility to infection by $A$. tumefaciens. Tumour tissue can be obtained 10 to 15 days following inoculation. Cefotaxime $\left(0.5 \mathrm{~g} \cdot 1^{-1}\right)$ was added to the Knop medium then to eliminate agrobacteria. The tumour tissue grew on parenchyma, which was maintained outside the Knop mixture, and only non-transformed part of parenchyma was thus immersed in the medium.

\subsection{Isolation and Purification of the Cytotoxic Agent}

Parenchyma of potato tubers (S. tuberosum L. cv agata) was cut in parallelepipeds (length $2 \mathrm{~cm}$, section $1 \times 1 \mathrm{~cm}$ ) that were left for $24 \mathrm{~h}$ in a sterile culture tube at $25^{\circ} \mathrm{C}$ in the dark for air-drying. Parenchyma pieces were transferred into tubes containing $3 \mathrm{ml}$ of sterile Knop medium, diluted two-fold, at $\mathrm{pH} 5.5$ for $2 \mathrm{~h}$. Only $1 / 3$ of tuber piece was thus immersed. Then, culture medium was collected and centrifuged at 10,000 g for 15 minutes. Supernatant was collected and dialysed for $4 \mathrm{~h}$ against distilled water under stirring at $4^{\circ} \mathrm{C}$ (Spectra dialysis membrane, porosity MWCO: 6 - 8000). Finally, mercaptoethanol $(8 \mathrm{mM})$ was added to prevent protein adsorption and the solution was filtered throughout Millex ${ }^{\mathrm{TM}}$ filter device, with PVDF Durapore ${ }^{\mathrm{TM}}$ membrane $(0.22$ $\mu \mathrm{m}$; Millipore, Bedford, USA). Such a sterile solution was called fraction $\mathrm{S} 1$, and could be stored at $4^{\circ} \mathrm{C}$ before use.

$\mathrm{S} 1$ fraction was then concentrated and small molecules were removed by using a centrifugal filter unit with a 10-kDa cut-off membrane (AMICON Ultra-15 10.000 MWCO, Millipore). Aliquots of $15 \mathrm{ml}$ were centrifuged for $10 \mathrm{~min}$ at $2800 \mathrm{~g}$. Fractions $(2 \mathrm{ml})$ then could be sterilized by filtration as described above. Protein fractions, approximately eight-fold concentrated, were called S2. Protein content was assayed according to Bradford [25] or using NanoOrange protein assay kit according to the supplier's protocol (Molecular Probes, Invitrogen, CergyPontoise, France).

\subsection{Protein Purification}

Proteins of S2 fractions were separated following their 
molecular weights on sephacrylamide (S300-HR, Sigma) column as previously described [3]. Polypeptides were eluted with phosphate buffer solution $(0.2 \mathrm{M}, \mathrm{pH} 7.5)$ and fractions of $3 \mathrm{ml}$ or $1 \mathrm{ml}$ were then recovered. Since patatin is a mannosyl glycoprotein, it can be precipitated by specific lectins, such as concanavalin A $\left(0.5 \mathrm{mg} \cdot \mathrm{ml}^{-1}\right)$. Following centrifugation (15 min, 12,000 g), pellet was dissolved again and run through concanavalin A column. Patatin-like polypeptides were finally removed from the support by $4 \%$ Methyl $\alpha$-d-mannopyranoside solution.

\subsection{Polyacrylamide Gel Electrophoresis (PAGEs)}

Non-denaturing PAGE was performed according to Clarke and Critchley [26]. Protein samples were separated on $10 \%$ polyacrylamide gel in Tris-glycine buffer ( $\mathrm{pH} 8.3$ ), with 4\% acrylamide for stacking gel in Trisglycine buffer ( $\mathrm{pH}$ 6.8). After electrophoretic separation, proteins or polypeptides were removed from gels by electro-elution (Biotrap System, Schleicher and Schuell), for $4 \mathrm{~h}$ under $200 \mathrm{~V}$ in a Tris-glycine buffer (Tris-HCl 25 $\mathrm{mM}$ and glycine $192 \mathrm{mM})$. Samples were sterilized through Millipore filters $(0.22 \mu \mathrm{m})$. Protein mixtures thus could be stored at $4^{\circ} \mathrm{C}$.

\subsection{D- or 2D-SDS-Polyacrylamide Gel Electrophoresis (SDS-PAGEs)}

Polypeptides were separated by SDS PAGE (in Apelex model V10-CDC apparatus), according to Laemmli [27] modified by Schagger and Von Jagow [28]. Protein samples were mixed with an equal volume of dissolving solution $(5 \% \mathrm{v} / \mathrm{v} 2-$ mercaptoethanol, $10 \% \mathrm{w} / \mathrm{v}$ glycerol, $4 \%$ $\mathrm{w} / \mathrm{v}$ SDS and $0.01 \% \mathrm{w} / \mathrm{v}$ bromophenol blue, in $0.5 \mathrm{M}$ Tris- $\mathrm{HCl}$ buffer $\mathrm{pH}$ 6.8), then heated in boiling water for $2 \mathrm{~min}$. An equal volume $(5 \mu \mathrm{l})$ for each sample was loaded on $12.5 \%$ or $15 \%$ polyacrylamide gels (4\% acrylamide for the stacking gel in a SDS-Tris-glycine buffer $\mathrm{pH}$ 6.8) in SDS-Tris-glycine buffer $\mathrm{pH}$ 8.8. Gels were stained either with silver nitrate according to Blum et al. (1987) [29], or with Coomassie Blue R250 (BioRad) [30].

Two-dimension isoelectrofocusing electrophoresis (2-D IEF PAGE) was performed according to O'Farrell [31]. Non-equilibrium $\mathrm{pH}$ gradient electrophoresis was done with fraction of secreted patatin-like proteins previously purified by PAGE in non-denaturing conditions [3]. First dimension was done in polyacrylamide gel $(6.4 \%$ acrylamide) containing ampholines $(\mathrm{pH} 3.5$ - $10(250 \mu \mathrm{l})$ or 5 $7(450 \mu \mathrm{l})$ : Pharmacia Biotech), at $4^{\circ} \mathrm{C}$, for $16 \mathrm{~h}(900 \mathrm{~V})$; electrophoresis was realized using $0.02 \mathrm{M} \mathrm{NaOH}$ solution in cathode tank and $0.01 \mathrm{M} \mathrm{H}_{3} \mathrm{PO}_{4}$ solution at anode.

Second dimension was performed by SDS-PAGE either with $12.5 \%$ acrylamide, for separation gel, in SDSTris-glycine buffer $\mathrm{pH} 8.8$ with a stacking gel $(5 \%$ acrylamide in SDS-Tris-glycine buffer $\mathrm{pH} 6.8$ ), or in $6 \%$ - 15\% acrylamide gradient gel (in SDS-Tris-glycine buffer $\mathrm{pH} 8.8$ ), for $5 \mathrm{~h}$ at $4^{\circ} \mathrm{C}$ with $25 \mathrm{~mA}$ constant current (EC-Apparatus Corporation gel column 7698 and Hoefer SE600 apparatus). Gels were stained with Coomassie Blue R250. Stained spots were cut from the gel and transferred onto a PVDF membrane for polypeptide sequencing. Molecular weights were evaluated by migration of Sigma Marker ${ }^{\mathrm{TM}}$ Low Range.

\subsection{Polypeptide Sequencing}

Polypeptide sequences were analysed by MALDI-TOF mass spectrometry ("Matrix Assisted Laser Desorption Ionisation-Times of Flight"). Polypeptides, purified by 2D IEF PAGE, were removed from gels and hydrolyzed with trypsin. Produced peptides were analysed in mass spectrometer (Voyager DEPRO Biosystems) and patterns were compared to Swiss Prot data bank from NCBI.

Amino-terminal polypeptide sequences were analysed after polypeptide separation by 2D-electrophoresis. Proteins were electro-blotted onto polyvinylidiene difluoride (PVDF) membrane (Bio-Rad, Marnes la Coquette, France), using semi-dry blotter system IMM-2 (The W.E.P. Company, Seattle, Wa., USA). Stained protein spots were cut off PVDF membrane, washed in distilled water and airdried before sequencing (Proseq). Amino-terminal sequences were obtained according to Edman and Begg [32], and compared with known proteins into amino acid sequence data base (NCBI, protein Blast Data base).

\subsection{In Vitro Test for Antitumour Effect on Plants}

Cytotoxic activities of S1, S2 or chromatography fraction solutions were tested on crown-gall tumour fragments, by direct application on tumour tissue or by dipping plant fragments into sterile Knop medium containing secreted products (dilution 1/2). Three replicates of eight tumour samples were used for each experiment.

\subsection{Animal Cell Culture and Colony-Forming Assay}

Anti-clonogenic effects were assayed on two murine cell lines: B16 melanoma cells and L929 immortalized fibroblastoid cells. B16 cells were obtained from the American Type Culture Collection (ATCC, Manassas, USA) and L929 from the European Collection of Cell Cultures (ECACC, Salisbury, United Kingdom). Cells were cultured in Minimum Eagle's Essential Medium (MEM, Gibco, Invitrogen, Cergy-Pontoise, France) supplemented with $1 \%(\mathrm{v} / \mathrm{v})$ vitamin cocktail, $1 \%$ glutamine, $1 \%$ non-essential amino-acids, $4 \mu \mathrm{g} / \mathrm{ml}$ gentamicin, and $10 \%$ foetal calf serum (Sigma, Les Abresle, France) at 
$37^{\circ} \mathrm{C}$ in hydrated air with $5 \% \mathrm{CO}_{2}$. Doubling time was around $15 \mathrm{~h}$ for both cell lines. B16 or L929 cells were plated into Petri dishes (40 $\mathrm{mm}$ in diameter; 150 cells/ plate) and incubated overnight before treatment. The medium was removed and fresh MEM containing either plant secretion, or purified fractions in different amounts, or control solution $(\mathrm{NaCl} 0.9 \% \mathrm{~m} / \mathrm{v})$ was added. Ten days later, plates were rinsed with PBS (Phosphate Buffer Saline; Invitrogen). Cells were fixed in methanol, and stained with $0.2 \% \mathrm{w} / \mathrm{v}$ crystal violet solution. Colonies containing more than 50 cells were counted and cell clonogenicity (percentage of cells forming colonies relative to control) was calculated. Each treatment was performed in triplicate and each experiment was at least duplicated.

\section{9. $P_{L} A_{2}$ Activity Assays}

$\mathrm{PLA}_{2}$ activity was evaluated by method of Radvanyi et al. [33]. Substrate used was a pyrene-associated phospholipid 1-Hexadecanoyl-2-(1-pyrenedecanoyl)sn-glycero-3phosphoglycerol ( $\beta$-pyC-10-PG; Molecular Probes ${ }^{\mathrm{TM}}$, Invitrogen). After phospholipid hydrolysis by $\mathrm{PLA}_{2}$ activity, the pyrene-probe free fatty acids bind tightly to BSA and fluoresces at $377 \mathrm{~nm}$ (excitation wavelength $342 \mathrm{~nm}$ ) which was quantified with a Fluoroskan Ascent FL reader. Measures were kinetically done, every $20 \mathrm{~s}$, for $3 \mathrm{~min}$ and reaction velocity was calculated by linear regression analysis. Phospholipase $\mathrm{A}_{2}$ from Naja mozambica (Sigma) was used as positive control.

$\mathrm{PLA}_{2}$ activity has been characterized using specific inhibitors like ATK (Arachidonyl trifluoromethyl ketone), PTK (Palmitoyl trifluorylmethyl ketone), BEL (Bromoenol Lactone, (E)-6-(bromomethylene)-3-(1-naphtalenyl) 2H-tetrahydropyran-2-one) and MAFP (Methyl Arachidonyl Fluorophosphonate) (Calbiochem, San Diego, USA).

\section{RESULTS}

\subsection{Secreted Protein Characterisation}

To characterize the active antitumour agent, the protein fraction of the plant secretion product was analysed. Non-denaturing PAGE of secretion products revealed three silver nitrate stained bands, two minor ones around $180 \mathrm{kDa}$ (band A) and $40 \mathrm{kDa}$ (band C) and a major band at $95 \mathrm{kDa}$ (band B) [3]. Using SDS-PAGE, we previously described two sets of polypeptides which comigrate in band B: a major polypeptide (MW 35 - 40 $\mathrm{kDa}$ ) and a smaller one (around $16 \mathrm{kDa}$ ) containing $\mathrm{Ku}-$ nitz-type protease inhibitors [3].

Analysis of the main protein spot, obtained in nondenaturing electrophoresis gel, by $2 \mathrm{D}$ isoelectrofocusing PAGE had displayed several polypeptide spots with close MW around $36 \mathrm{kDa}$ (Figure 1 spot B1). Other

pH

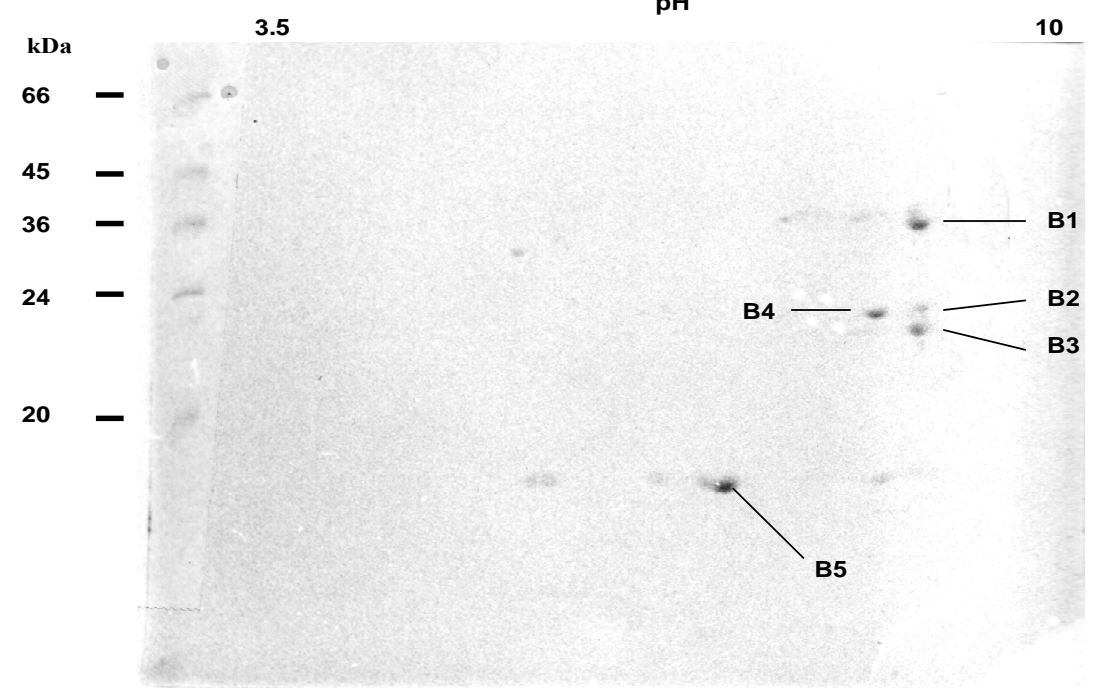

Figure 1. 2D IEF electrophoresis of patatin-secreted product Non equilibrium $\mathrm{pH}$ gradient elecrophoresis was realised on a fraction of secreted $\mathrm{PLA}_{2}$-like patatin previously purified and separated in polyacrylamide gel, after an electrophoresis in non-denaturing conditions. First dimension was done in polyacrylamide gel (6.4\%) with ampholines $(250 \mu \mathrm{l}$ ampholines $3.5-10$ and $450 \mu \mathrm{l}$ ampholines $5-7)$, at $4^{\circ} \mathrm{C}$, for $16 \mathrm{~h}$, at $900 \mathrm{~V} ; 2^{\text {nd }}$ dimension was realised by SDS-PAGE $\left(12.5 \%\right.$ acrylamide, $4^{\circ} \mathrm{C}, 5 \mathrm{~h}$, $25 \mathrm{~mA}$ ). Gel was stained with Coomassie Blue R250. Stained spots B 1 - 5 were cut off gel and transferred onto a PVDF sheet for sequence analysis of polypeptides. Polypeptides are described in Table 1. Molecular weights were obtained by migration of Sigma Marker ${ }^{\mathrm{TM}}$ Low Range (M). 
smaller spots, around 24 - $30 \mathrm{kDa}$ (spots B2-4), were possibly stained (Figure 1). N-terminal sequence analysis of four of the main polypeptide spots, separated on 2D gels, have shown a sequence related to patatin polypeptide, but with amino-acid differences for one out of patatin spots (Table 1). Variations of sequences mainly occurred at the level of first and third N-terminal amino acid. A protease inhibitor (spot B5) often is associated to patatin complex (Figure 1) [3]. 2D IEF spots were removed from gel and analysed by MALDI-TOF method (Table 1). Spots B1, B2 and B4 were shown to contain the ion 1437 and the spot B3 to have ion 1464. Data thus demonstrate that at least two isoforms of patatin were released in our experimental conditions. Amino terminal sequences for polypeptide spots of secreted patatin displayed a nucleotide-binding consensus motif GGGIKG that was observed in $\mathrm{iPLA}_{2}$ gene family [24]. Moreover, analysed spots displayed sequence GGGIKGII described in PLLA $_{2} \alpha$ sequence (40 kDa, 386 amino-acids) from mammals [34].

Polypeptides of secretion fraction S2 can be eventually separated by exclusion chromatography through a sephacrylamide column. Protein content of each eluted fraction was analysed by SDS-PAGE (Figure 2(a)). A $40 \mathrm{kDa}$ polypeptide was found purified in fractions $6 \mathrm{a}-\mathrm{c}$ (F6). Plant antitumour activity, previously observed with purified secretion products (S1 or S2), was present in fraction F6 but not in other fractions. 2D IEF-PAGE analysis of fraction F6 showed several spots between 36 and $40 \mathrm{kDa}$, with a pI ranging from 6 to 7 , but did not contain any protease inhibitor spots (data not shown).

To assess whether the proteins leave the tissue passively or by secretory pathway, we compared protein patterns obtained with or without orthovanadate treatment,

Table 1. N-terminal sequences of main polypeptides associated to the excreta of potato tuber parenchyma. Spots are called and molecular weights are observed on the 2D IEF gel in Figure 1. N-terminal sequence analysed and nucleotide-binding consensus motif GGGIKG, which is observed in the iPLA 2 gene family, are displayed in bold and underlined. Molecular weights (MW) were given by database.

\begin{tabular}{|c|c|c|c|c|c|c|c|}
\hline \multirow{2}{*}{ Name } & \multirow{2}{*}{ Sequence } & \multirow{2}{*}{ Sequence Homology } & \multicolumn{5}{|c|}{ MALDI-TOF mass spectra data } \\
\hline & & & accession number & score & matched peptide cover & $\mathrm{pI}$ & MW \\
\hline $\mathrm{B} 1(36 \mathrm{kDa})$ & TLGEMVTVLSIDGGGIKGII & Patatin-like protein & 129642 & $6.10^{4}$ & $25 \%$ (386 aa) & 5.5 & 42613 \\
\hline B4 $(29 \mathrm{kDa})$ & TLGEMVTVLSIDGGGIKGII & Patatin-like protein & 129640 & $9.10^{3}$ & $14 \%$ (386 aa) & 5.3 & 42491 \\
\hline B2 (29 kDa) & TLGEMVTVLSI(P)(A)GG & Patatin-like protein & 82272 & $5.10^{3}$ & $11 \%(384 \mathrm{aa})$ & 5.5 & 42356 \\
\hline B3 (24 kDa) & SLEEMVTVLSIDGGGIK()II & Patatin-like protein & 7442017 & $2.10^{4}$ & $20 \%(386 \mathrm{aa})$ & 5.4 & 42629 \\
\hline B5 (16 kDa) & LPSDATPVLDVTGKELDPR(L) & Kunitz-type proteinase inhibitor & 2129993 & $5.10^{4}$ & $37 \%$ (221 aa) & 5.9 & 24097 \\
\hline
\end{tabular}

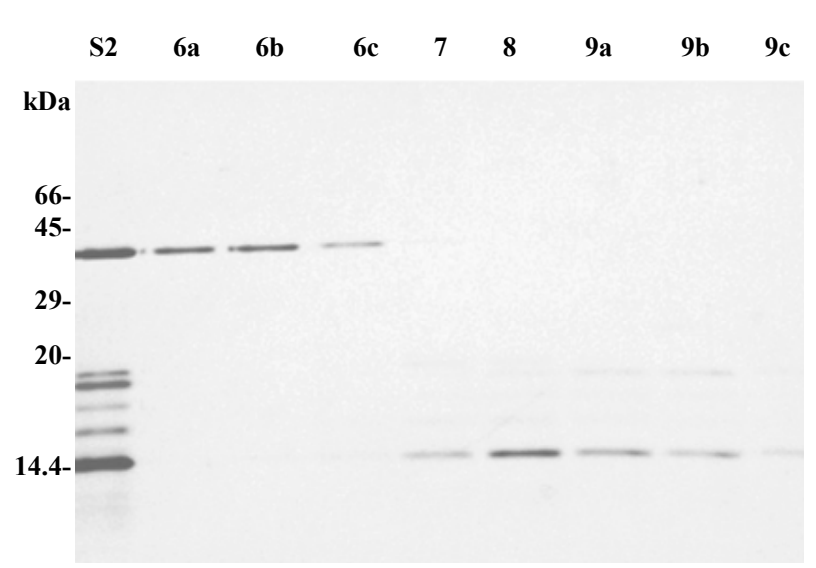

(a)

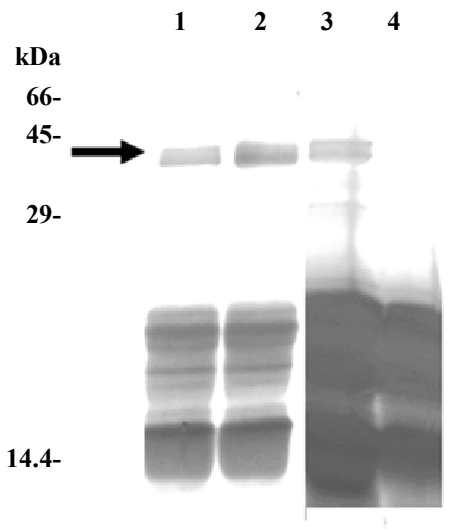

(b)

Figure 2. Analysis of purified secreted patatin. (a) Purified secretion product (S2), and fractions obtained from sephacrylamide column, were analysed by SDS-PAGE (15\% acrylamide, $110 \mathrm{~V}, 20 \mathrm{~h}$ ). Samples had either a volume of $3 \mathrm{ml}$ (fractions 7 , 8) or $1 \mathrm{ml}$ (fractions 6a, 6b, 6c and 9a, 9b, 9c). (b) SDS-PAGE analysis of effect of vanadate on patatin secretion. Pieces of tuber parenchyma were put in Knop solution for 2 hours just after cutting (lanes 1 and 2) or after a $48 \mathrm{~h}$ drying period at $25^{\circ} \mathrm{C}$ (lanes 3 and 4). Each sample was either supplemented with $1 \mathrm{mM}$ orthovanadate (lanes 2 and 4 ) or did not contain any vanadate (lanes 1 and 3). Arrow indicates patatin polypeptides (40 kDa). SDS-PAGE was performed in $12.5 \%$ polycrylamide gel (separation gel: $12.5 \%$ acrylamide; stacking gel: $5 \%$ acrylamide; $4.5 \mathrm{~h}, 30 \mathrm{~mA}$ ). 
an inhibitor of multiple ATPases. Sodium orthovanadate is a well-known inhibitor of numerous ATPases or phosphatases, by acting as phosphate analogue [35]. In plants, orthovanadate is commonly used to inhibit ATPbinding cassette transporters [36]. When freshly cut pieces of tuber parenchyma were dipped into hydration solution with or without $1 \mathrm{mM}$ sodium orthovanadate, a same polypeptide pattern was obtained in $40 \mathrm{kDa}$ spot region after SDS-PAGE. Conversely, after a drying period $(48 \mathrm{~h})$, that allows healing up parenchyma wounds, secretion product of water-stressed tuber parenchyma displayed a different pattern after orthovanadate treatment: $40 \mathrm{kDa}$ band was missing in presence of orthovanadate (Figure 2(b)). Therefore, after a drying period, polypeptide releases were not due to leakage of intracellular proteins, suggesting that patatin-like proteins might be secreted via an active, orthovanadate-sensitive process.

\subsection{PLA $A_{2}$ Activity of 40 kDa Protein Group}

To assess whether $40 \mathrm{kDa}$ protein group exhibited $\mathrm{PLA}_{2}$ activity, lipid esterase activity was measured with $\beta$ pyC-10-PG, a pyrene-labeled acidic phospholipid. Since, only $s n-2$ phospholipid acyl chain is labelled, $\beta$ pyC-10-PG can discriminate between phospholipase $\mathrm{A}_{2}$ and phospholipase $A_{1}$ activities. Pyrene fluorescence is quenched by interactions with lipid matrix and increases upon cleavage of probe by phospholipase activity. Secreted proteins (S2) induced concentration-dependent release of pyrene and this activity was seven to eight-fold higher in fraction F6 (Figure 3(a)). PLA $\mathrm{P}_{2}$ activity was inhibited by ATK, PTK, and to a lesser extent by MAFP (Figure 3(b)), which are well-known inhibitors of $\mathrm{cPLA}_{2}$ and PLA $_{2}$ activities [16,35-38]. BEL up to $20 \mu \mathrm{M}$, an iPLA $_{2}$ inhibitor [39,40], had, at most, a slight effect on

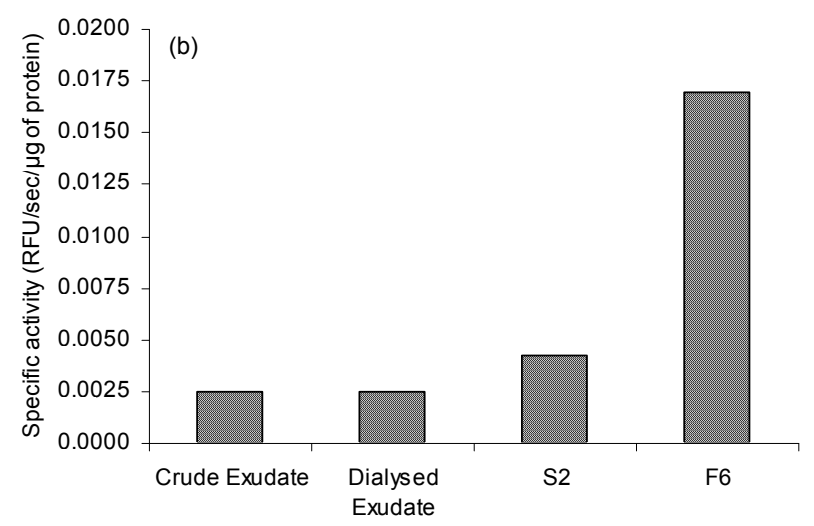

$\mathrm{PLA}_{2}$ activity of secreted patatin-like protein (data not shown). Finally, addition of EGTA $(100 \mu \mathrm{M})$ did not change PLA $_{2}$ activity of secreted patatin-like protein (data not shown). This pattern of inhibitor sensitivity fits well with calcium-independent $\mathrm{CPLA}_{2}$ activity of the secreted patatin-like protein.

\subsection{Secreted Product from Injured and Water-Stressed Potato Tubers Induces Anti-Crown-Gall Effect}

To investigate antitumor effect of secreted product on plants, experiments were performed using crown-gall tissue obtained from $H$. tuberosus tubers previously infected by Agrobacterium tumefaciens. Purified protein Fraction 6 secreted by potato tubers was added locally to plant tumour fragments cut off from parenchyma or in situ. Necrosis of tumour tissue was observed two days after treatment (Figure 4). Secreted product first induced a brown colour of plant tumour tissue, and a complete necrosis was achieved after $48 \mathrm{~h}$. When secreted product was applied in situ, no effect was observed on healthy parenchyma tissue. Finally, cytotoxic effect was lost when secreted proteins were denatured by precipitation with ammonium sulphate (data not shown).

Since patatin-like protein of secreted product showed $\mathrm{PLA}_{2}$ activity, as previously reported for the vacuole-stored patatin, and the latter is known to be retained on a concanavalin A column, we investigated whether this was also a feature of the secreted product. $\mathrm{PLA}_{2}$ activity was observed after purification of $40 \mathrm{kDa}$ polypeptide by concanavalin-affinity chromatography (Figure 5(a), lane C). In contrast, the fraction of secretion product, that was not retained on column and deprived of 40-kDa-protein, had no significant PLA $_{2}$ activity (Figure 5(a), lane N).

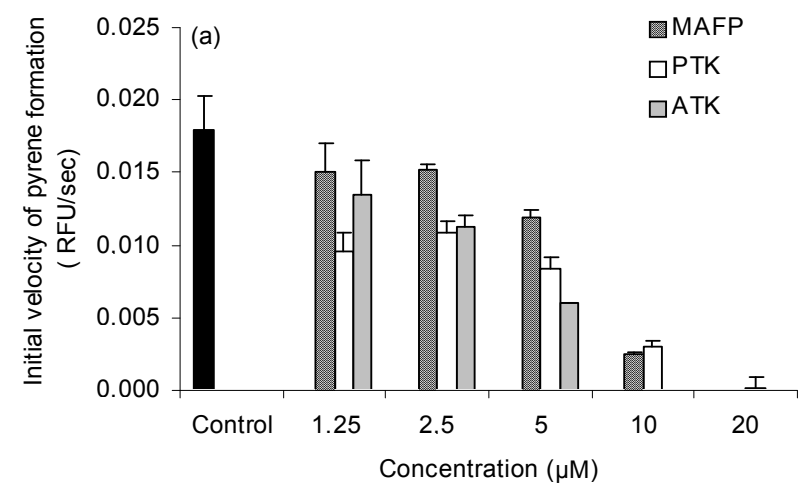

Figure 3. $\mathrm{PLA}_{2}$ activity of purified secreted patatin. (a) Purification of secreted PLA $\mathrm{A}_{2}$ following enzyme activity. Each extract corresponds to protocol described in experimental procedure. $\mathrm{PLA}_{2}$ specific activity is given for each step of purification. Results are representative of five independent experiments. (b) Sensitivity of secreted PLA 2 activity to specific PLA 2 inhibitors. Fraction S2 of secreted patatin-like PLA $\mathrm{P}_{2}$ was mixed with $0.01 \%$ (v/v) DMSO (control; black histogram) or MAFP (striped), PTK (white) or ATK (grey), at indicated concentrations. Fraction S2 was a purified secreted product that was 4-fold concentrated prior to use. These results are representative of three independent experiments. 


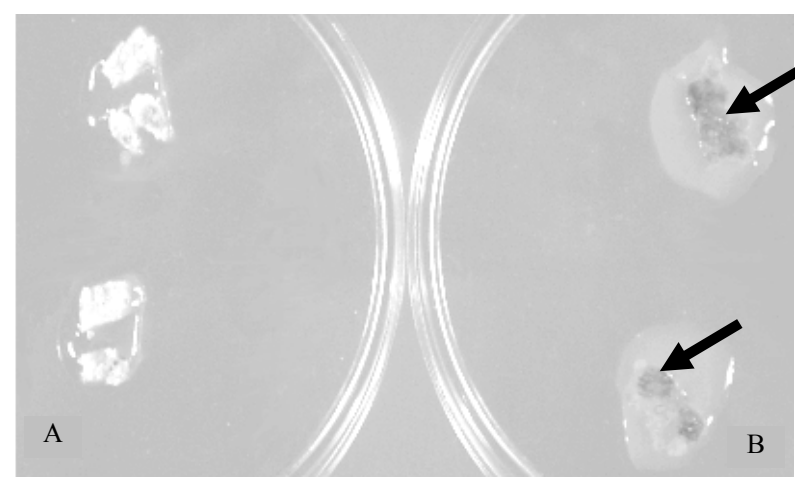

Figure 4. Effect of a purified fraction on plant tumour cells. Crown-gall tissue was obtained on a piece of $H$. tuberosus tuber parenchyma. Fragments of tumour tissue were put either into distilled water (Petri plate A) or in a Petri plate containing $40 \mathrm{kDa}$ polypeptides (Fraction 6 from sephacrylamide column; Petri plate B). Tumour tissues were observed two days later. Arrows show areas of necrotic tissues.

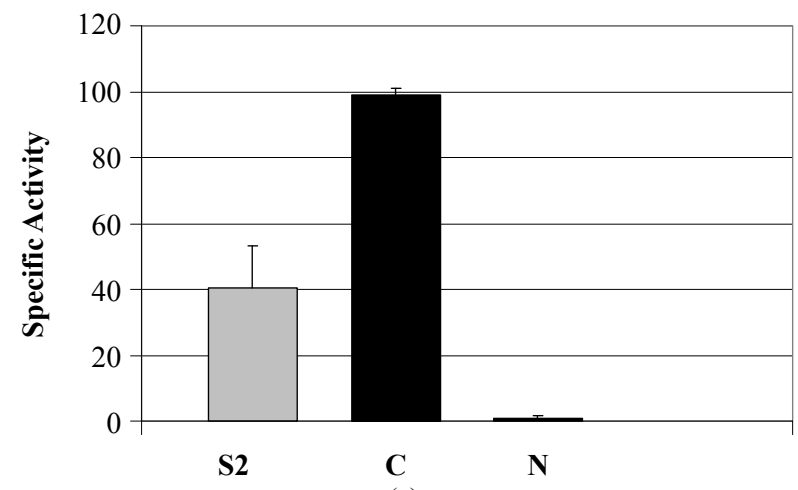

(a)

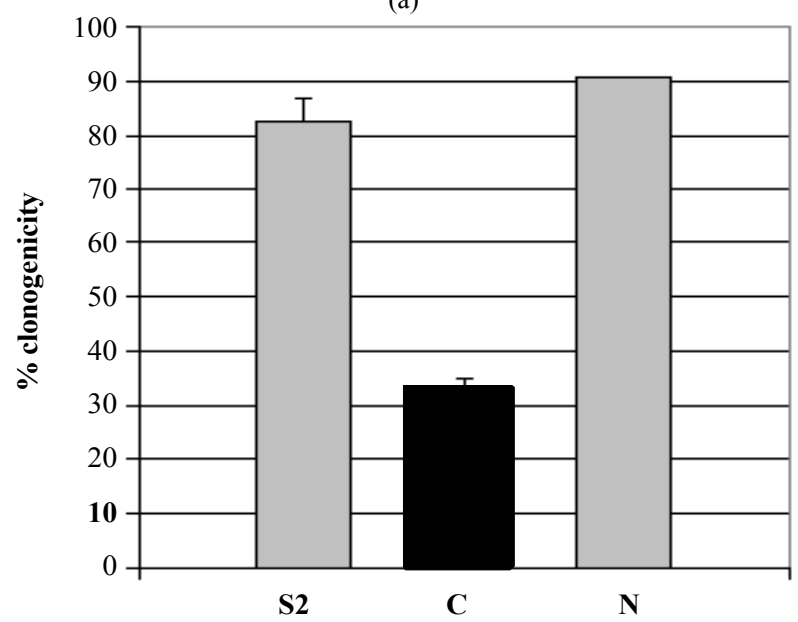

(b)

Figure 5. Specificity of secreted patatin polypeptide activity against B16 melanoma cells. (a) PLA 2 activity of different kind of secreted fraction, such as fraction S2, patatin-like protein fraction retained on Concanavalin A column (C) and fraction not retained on column $(\mathrm{N})$ that was shown to be deprived of patatin-like polypeptides. $\mathrm{PLA}_{2}$ specific activity is given as $10^{-6} \mathrm{RFU} / \mathrm{sec} / \mu \mathrm{g}$ protein. (b) Clonogenicity of B16 cells after treatment with similar concentrations of protein in comparison with control cell cultures.

\subsection{Cytotoxicity on Murine Tumour Cells}

To evaluate secreted product as potential agent against mammal tumours, its cytotoxicity was investigated in vitro by colony-forming assay both on murine B16 melanoma cells and on murine L929 non-tumour cells (Figure 5(b)). Cytotoxicity against B16 cells was correlated to increased patatin-like polypeptide purified by concanavalin A (Figure 5(b)), compared with crude product (S2). In contrast, fraction of the product that was not retained on column (and thus depleted for 40kDa-protein), had no significant $\mathrm{PLA}_{2}$ activity (Figure 5(a), lane $\mathrm{N}$ ) and displayed a reduced cytotoxicity against B16 cells (Figure 5(b), lane N).

Although purified fraction F6 showed no cytotoxicity on L929 fibroblasts in the same range of concentrations, a dramatic decrease of clonogenicity was observed for B16 melanoma cells treated with either secreted product (data not shown) or purified fraction F6 (Figure 6). Cytotoxic activity was thus concentration-dependent and purified fraction $\mathrm{F} 6$ showed an $\mathrm{IC}_{50}$ of approximately $0.42 \mu \mathrm{g}$ protein $\mathrm{ml}^{-1}$ on $\mathrm{B} 16$ cells.

\subsection{PLA $\mathrm{A}_{2}$ Activity Inhibition and Cytotoxicity}

MAFP and PTK inhibitors at $10 \mu \mathrm{M}$ decreased cytotoxic activity of secreted protein against B16 cells, while ATK had an intermediate effect and BEL did not show any effect (Figure 7). Moreover, addition of EGTA (100 $\mu \mathrm{M})$, a calcium chelator, did not modify cytotoxicity of secreted product. Therefore, $\mathrm{PLA}_{2}$ activity described above is at least in part involved in a specific cytotoxicity of secreted proteins against B16 melanoma cells.

\section{DISCUSSION}

Following a water stress, wounded potato tuber parenchyma secreted products including several proteins during rehydration period that were toxic against tumour cells in vitro. Potato tubers cut into pieces and air-dried in sterile tubes displayed a scar tissue as described by Baji et al. [41]. Active agent, which involved one 36-40 $\mathrm{kDa}$ protein, or possibly a protein complex, is related to patatin-like PLA $\mathrm{PL}_{2}$. It induced specific cytotoxicity against plant crown-gall cells and against murine B16 melanoma cells. Two or four cycles of desiccation-rehydration also produced secretion of cytotoxic agent. In addition, sodium orthovanadate, commonly used to inhibit ATPbinding cassette transporters [36], prevented secretion of patatin-like polypeptide. It is likely that an ATP-dependent cellular process is involved in $40 \mathrm{kDa}$ fraction secretion. This may suggest that secretion is involved in and as-yet undescribed plant defence system activated by a stress.

Main protein was purified from plant secreted product 


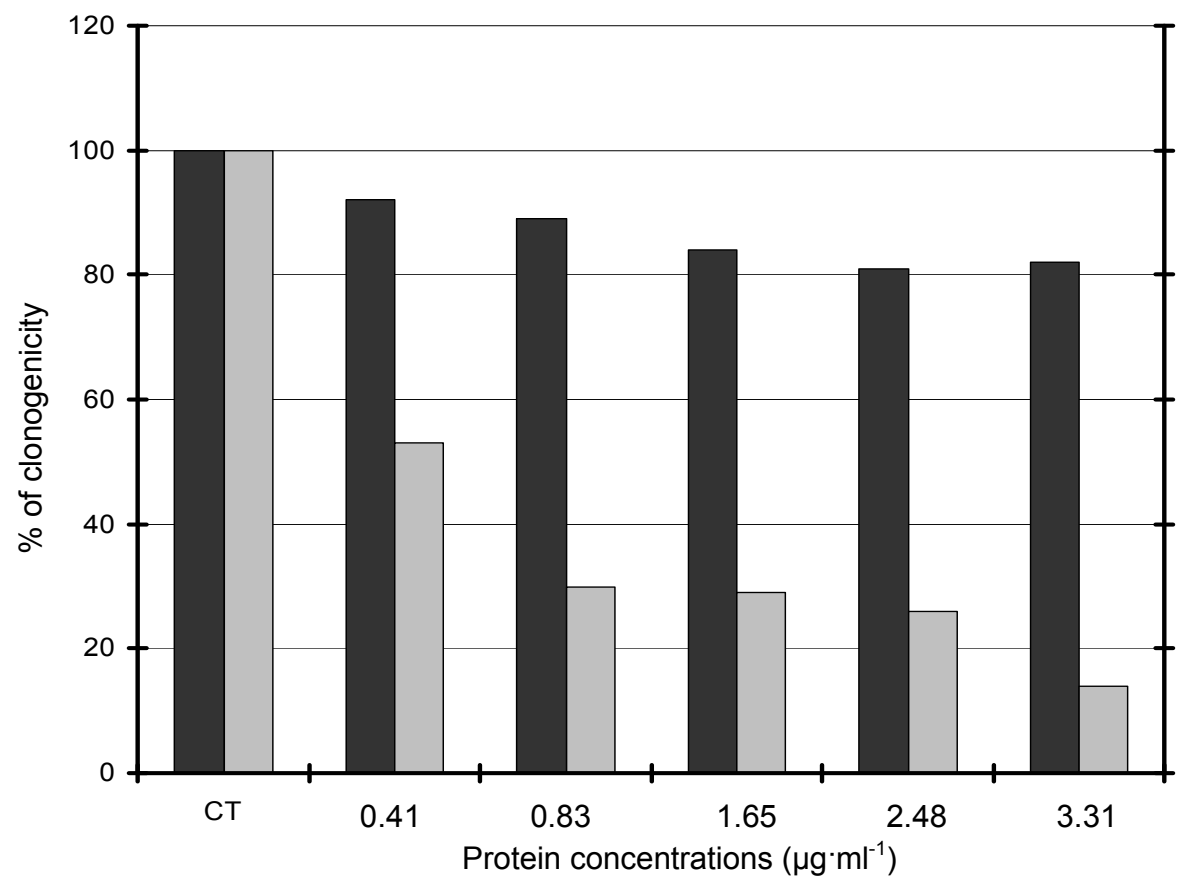

Figure 6. Clonogenicity of B16 melanoma cells treated with purified fraction 6. Concentration-dependent cytoxicity of sephacrylamide-separated fraction 6 was investigated using a colony forming assay of B16 cells (grey histograms) and L929 immortalized fibroblasts (black histograms). Clonogenicity was expressed as \% of control cells CT (untreated B16 and $\mathrm{L} 929$ cells respectively). Observed $\mathrm{IC}_{50}$ was $0.42 \mu \mathrm{g} \cdot \mathrm{ml}^{-1}$.

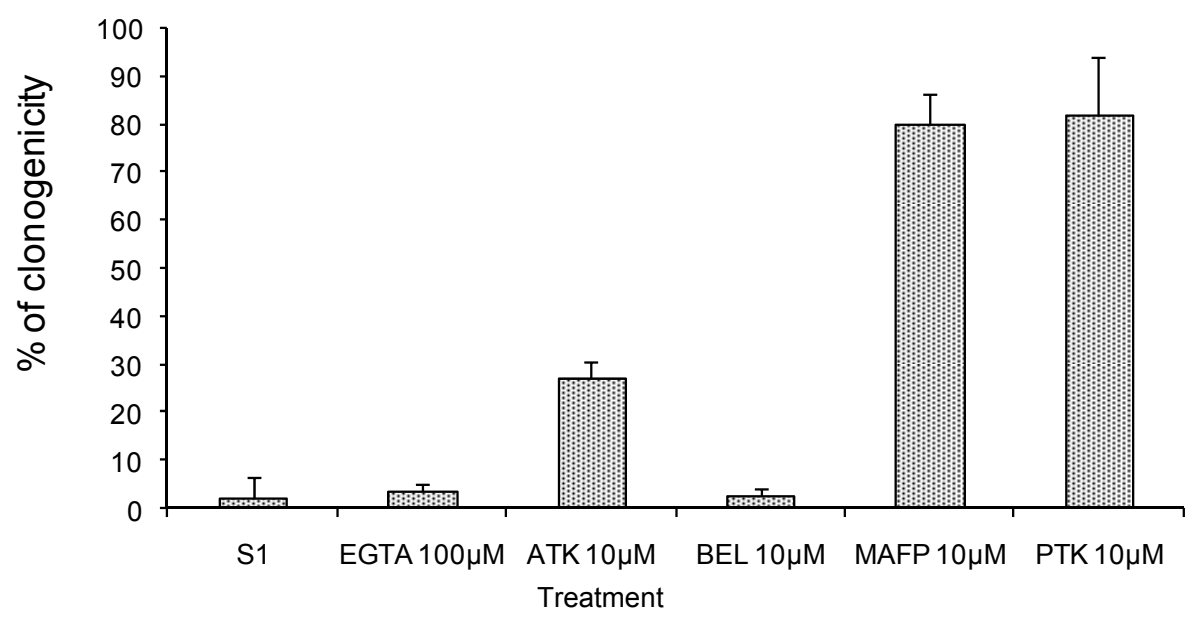

Figure 7. Effects of PLA 2 inhibitors (EGTA $100 \mu \mathrm{M}$, ATK $10 \mu \mathrm{M}$, BEL $10 \mu \mathrm{M}$, PTK 10 $\mu \mathrm{M}, 2,4 \mathrm{D} 10 \mu \mathrm{M})$ associated with secreted patatin-like protein treatment on B16 cell viability. Fraction S2 was a purified secretion product that was 4-fold concentrated prior to use; each experimental sample contained $3.5 \mu \mathrm{g}$ of secreted patatin-like protein.

through sephacrylamide column and was shown to belong to patatin family. Secreted patatin-like product could be recovered from plant product by concanavalin A lectin engrafted column, as described for intra-cellular patatin [37]. SDS-PAGE pattern of patatin-like protein retained on concanavalin A column, showed a pattern similar to the fraction 6 polypeptides separated on sephacrylamide column (Figure 3), and have been used for enzyme and cytoxicity assays with similar results. In plants, patatin is mainly observed in vacuoles of tuber cells, and sometimes in cytosol. However, it was shown that treatment of potato tubers by elicitors such as jasmonic acid, salicylic acid or arachidonic acid, promotes excretion of patatin and chymotrypsin inhibitors [38].

Amino terminal sequence of secreted patatin-like polypeptides displayed a nucleotide-binding consensus 
motif GGGIKG previously described in mammalian iPLA $2 \alpha$ sequence (40 kDa, 386 amino acids) [34] (Table 1). This sequence was localised 12 amino acids aside from N-terminal end of secreted patatin-like sequence, versus 36 amino acids from $\mathrm{N}$-terminus in mammal iPLA $_{2}$. The sequence SIDGGG, which is displayed, was previously described in human iPLA $\mathrm{A}_{2} \alpha$ sequence [39].

Patatin-like proteins from several plant sources have been reported to exhibit $\mathrm{PLA}_{2}$ activity [40]. Structural analysis of plant lipid acylhydrolase patatin revealed that it also contained a Ser/Asp catalytic dyad and an active site structurally similar to $\mathrm{cPLA}_{2} \alpha$ [14]. Patatin-like $\mathrm{PLA}_{2}$ size in animals and plants ranges from 40 to 48 $\mathrm{kDa}$, and purified enzyme from broad beans, was inhibited by mammalian $\mathrm{iPLA}_{2}$ and $\mathrm{CPLA}_{2}$ inhibitors [42]. Our work has shown that secreted patatin-like protein complex displays $\mathrm{PLA}_{2}$ enzyme activity, but with special features. Addition of ATK, PTK, and to a lesser extent MAFP, which are well-known inhibitors of $\mathrm{cPLA}_{2}$ and iPLA $_{2}$ activities, decreased enzyme activity of secreted patatin-like protein. In contrast, BEL, which specifically inhibits iPLA $_{2}$ activity, did not significantly decrease lipid acyl hydrolase activity of the product, and addition of EGTA, a calcium chelator which inhibits cPLA 2 activity, also did not decrease acyl hydrolase activity. Therefore, secreted patatin-like protein displayed unusual features for $\mathrm{PLA}_{2}$ activity, and could be classed as BEL-insensitive iPLA . $_{2}$

Sensitivity of lipolytic enzymes to different chemical inhibitors can also be used to discriminate active sites in subfamilies. For example, pPLA and $\mathrm{iPLA}_{2}$ share a sensitivity against BEL inhibitor (also called HELSS), showing again their close catalytic properties. Regulation of cell death is also inhibited by BEL so that the relevant protein was shown to have characteristics of a pPLA $[4,43]$.

Altered lipid biosynthesis and deregulated lipogenesis are typical features of cancer [44]. We showed that $\mathrm{PLA}_{2}$ activity was required for cytotoxic effect on B16 melanoma cells. It induced cell death of crown-gall and inhibited clonogenicity of B16 cells, but, at same concentration, was not toxic for non-transformed cells. Inhibition of B16 cell clonogenicity was correlated to increase of $\mathrm{PLA}_{2}$ activity in fraction used for treatment (Figure 5) and cytotoxicity was shown to be sensitive to same PLA inhibitors. Moreover, secreted product cytotoxicity was lost after protein precipitation with ammonium sulphate or when $40 \mathrm{kDa}$ polypeptide group was depleted. These data are in agreement with direct cytotoxic effect of $\mathrm{PLA}_{2}$ activity of $40 \mathrm{kDa}$ patatin-like polypeptide. Otherwise, cell-stored patatin of plants, a form of $\mathrm{CPLA}_{2}$, and $\mathrm{sPLA}_{2}$ from naja were ineffective against plant tumour and melanoma B16 cells (data not shown).

Although PLA $\mathrm{PL}_{2}$ biochemistry is well documented, its mechanism of tumor cell cytotoxicity is still the subject of much debate. Several studies have shown correlation between epidermal growth factor receptor (EGFR) expression and sensitivity to $\mathrm{PLA}_{2}[45,46]$. However, both stimulatory and inhibitory effects have been reported, perhaps due to $\mathrm{PLA}_{2}$ and cell type and/or concentration effects. SPLA2 has been explored as an anticancer agent in its own right [47] as the active component of nanosized drug delivery systems [44,45]. Lei et al. [48] suggest that $\operatorname{iPLA}_{2} \beta$ activates a unique signaling cascade that promotes $\beta$-cell apoptosis. These observations indicate that $\mathrm{p} 38$ MAPK is activated downstream of $\mathrm{iPLA}_{2} \beta$ in $\beta$-cells and that $\mathrm{p} 38$ MAPK is involved in the $\beta$-cell functional responses of insulin secretion and apoptosis in which $\mathrm{iPLA}_{2} \beta$ participates [49]. Otherwise, Protobothrops flavoviridis venom contains plural phospholipase $\mathrm{A}_{2}$ isozymes that induced apoptotic cell death, neither inhibited by inhibitors of caspases 3 and 6 nor accompanied by activation of procaspase 3 , indicating that BPII-induced cell death was caspase independent, and mediated via cell-surface receptor [50]. Moreover, the inhibitory action of viper sPLA(2)s towards cancer cells depended on both venom and cell type. VBBPLA (Vipera berus berus) inhibited significantly the viability of K-562 cancer cells and the cell death appeared apoptotic. The $\mathrm{SLA}_{2} \mathrm{~s}$ exhibited no inhibitory effect towards LNCaP cancer cells and some effect towards other cells [51].

Recently, an extracellular multifunctional protein, PEDF, belonging to the serpin superfamily with a demonstrable antitumorigenic property, was shown to have a high affinity for the plasma membrane protein PEDF-R, which displays a phospholipase $A_{2}$ activity [52]. The authors suggested that PEDF-R may produce extracellular bioactive lipids, which can diffuse back into the cell as signalling molecules. PEDF, by binding to membrane-localized PEDF-R, may stimulate release of specific fatty acids and lysophospholipids, irreversibly damaging tumour cells $[52,53]$.

${ }_{i P L A}$ is in common use for animal enzymes. PLA $_{2}$ induced apoptosis in U937 human monocytic leukaemia cells [34]. This effect is associated with hydrolysis of arachidonic acid from membrane phospholipids through a mechanism inhibited by BEL, and was not catalysed by $\mathrm{SPLA}_{2}$ or by $\mathrm{cPLA}_{2}$. Arachidonic acid may serve to activate caspases and other downstream apoptotic signalling pathways [54]. Patatin-related proteins in plants, animal $\mathrm{iPLA}_{2} \mathrm{~S}$ and many bacterial proteins are characterized by having a catalytic center consisting of esterase box GTSTG and phosphate- or anion-binding element DGGGXRG [22]. These sequence elements are also present in iPLA $2 \alpha$, iPLA $_{2} \beta$ and iPLA $2 \gamma[4,40]$.

Extracellular and intracellular PLA $_{2}$ isozymes have been implicated in several types of apoptosis [55-57]. 
Antitumour factors such as TNF $\beta$ trigger $\mathrm{PLA}_{2}$ activity in macrophages, similar in molecular weight and $\mathrm{PLA}_{2}$ inhibitor sensitivity to that described here [55]. Inhibition of iPLA $_{2}$ protected against chemotherapeutic-induced cell death in human renal cell models, and identified specific phospholipids whose levels are altered during cell death [58]. Activation of phospholipase $A_{2}$ was shown potently to induce apoptosis [59].

Aside from its enzymatic activity, secreted patatin-like protein may also influence tumour growth through its ability to act as a ligand for M-type receptor, thereby activating downstream signalling pathways that influence proliferation or apoptosis, as described for PPLA $_{2}$-IIA $[60,61]$.

We have shown a specific activity against tumour cells. One of the main differences between tumour and healthy animal cells lies in the fact that their lipid compositions and distributions are different. In normal conditions, membrane phospholipids are asymmetrically distributed across cell membrane monolayers, with phosphatidylserine (PS) and phosphatidylethanolamine (PE) located on inner face, and sphingomyeline (SM) and phosphatedylcholine (PC) on outer face $[62,63]$. Asymmetric distribution of lipids was also observed in plasma membrane of tumour cells, but with reversed localization for phosphatidylserine (PS), which is present on outer face [64]. Remarkably, numerous tumour cell lines have been reported to display 3- to 7-fold elevated amounts of PS on exoplasmic membrane leaflet compared with nontumorigenic cells [65]. Therefore, we can suggest that different patatin-like proteins, and especially secreted patatin, may have different substrate preferences, as indicated by earlier results for other patatin-like products [66]. Thus, iPLA 2 -like enzyme (secreted patatin-like protein, e-patatin), whose secretion from potato tubers is triggered by physical stress, may recognize and mainly bind anionic phospholipids PS or PE, localized on external leaflet of tumour cell membrane. It was shown that bee venom $\mathrm{PLA}_{2}$ membrane interaction was mediated by a domain mainly composed by hydrophobic residues and two basic residues promoting interaction with anionic phospholipids such as phosphatidylserine (PS) [44]. Thus, both electrostatic and hydrophobic interactions determine location of $\mathrm{PLA}_{2}$ relative to membrane bilayer $[67,68]$.

$\mathrm{PLA}_{2}$ activity of secreted patatin-like protein would hydrolyse phospholipids into an inducer of apoptosis or necrosis, such as free arachidonic acid or specific lysophosphatidic acid. It was shown that arachidonic acid administration caused apoptosis in Y79 cells, as shown by typical morphological changes, phosphatidylserine externalization, chromatin condensation, processing and activation of caspase- 3 and cleavage of the endogenous caspase substrate poly-(ADP-ribose)-polymerase [59]. Arachidonic acid itself could induce apoptosis in cultured cells. These observations provide evidence that arachidonate may be involved in apoptosis in animal cells $[69,70]$. Arachidonic acid treatment was accompanied by increased formation of the lipid peroxidation end products malondialdehyde and 4-hydroxy-2-nonenal [59]. Arachidonic acid (AA) was described as lipid messenger derived through cleavage of membrane phospholipids by phospholipase $\mathrm{A}_{2}\left(\mathrm{PLA}_{2}\right)$ [71]. Exogenous arachidonic acid caused apoptosis in colon cancer and other cell lines [72]. One is to use phospholipase $A_{2}$ $\left(\mathrm{PLA}_{2}\right)$ to cleave phospholipid heads of the bilayer of cancer cells [73]. Correlative and functional studies involved expression of some secreted enzymes $\left(\mathrm{sPLA}_{2} \mathrm{~s}\right)$, particularly the best studied enzyme Group IIA sPLA $\mathrm{A}_{2}$ in either tumour promotion or inhibition, depending on organ involved and biochemical microenvironment of tumours [74].

Apoptosis in HL-60 cells, induced by blocking arachidonate-phospholipid remodeling, is correlated with redistribution of arachidonate in membrane phospholipids and suggest that such alterations represent a signal which controls capacity of cells to proliferate [75]. Arachidonic acid (AA) is not only a major structural constituent of membranes and a key precursor of various bioactive molecules (eicosanoids in particular), but it is also a second intracellular messenger. Its release from membrane phospholipids occurs upon several hormonal stimuli and in the course of pathological situations, ischemia injury in particular. This mainly relies on the activation of phospholipases $\mathrm{A}_{2}\left(\mathrm{PLA}_{2}\right)$, but may also involve phospholipases $\mathrm{C}$ or $\mathrm{D}$, and results in an increase in intracellular level of unesterified AA and is a good candidate as mediator of apoptosis triggered by TNFalpha, a role of AA which has been formally established in human leukemia cells [76]. Arachidonic acid released by Phospholipase $\mathrm{A}_{2}$ activation triggers $\mathrm{Ca}^{2+}$-dependent apoptosis through mitochondrial pathway [77].

Mitochondrial COX-2 in cancer cells confers resistance to apoptosis by reducing the proapoptotic arachidonic acid [78]. Natural $\mathrm{PLA}_{2}$ activity, as well as each subtype of $\mathrm{PLA}_{2}$ activity was elevated in each cancer group as compared to healthy controls. Phospholipase $\mathrm{A}_{2}$ enzymes $\left(\mathrm{PLA}_{2} \mathrm{~s}\right)$ are major enzymes producing cyclooxygenase-2 (COX-2) substrate, arachidonic acid (AA), as well as lysophospholipids. Both of these classes of products are signaling molecules involved in cancers. More importantly, their enzymatic activities, but not necessarily their RNA and/or protein expression levels, are directly related to biological effects, since $\mathrm{PLA}_{2}$ activities are well-known to be regulated post-transcriptionally [79-81]. Cytotoxicity of arachidonic acid appeared to involve lipid peroxidation mechanism. Arachidonic acid-induced apoptosis of human neuroblastoma SK-N-SH cells is mediated through mitochondrial al- 
teration elicited by ROS and $\mathrm{Ca}^{2+}$-evoked activation of p38 $\alpha$ MAPK and JNK1 [82]. It is notable that lipoapoptosis, induced by palmitic acid in human hepatocytes, was dependent on $\mathrm{PLA}_{2}$-generated lysophosphatidylcholine (LPC). It could be blocked by $\mathrm{PLA}_{2}$ inhibitors. Since, in plants, strong $\mathrm{PLA}_{2}$ induction precedes appearance of hypersensitive cell death, and various PCD types could either be accelerated or postponed by $\mathrm{PLA}_{2}$ overexpression or suppression, respectively, it can be proposed that $\mathrm{PLA}_{2}$ exerts its function in plant defense responses through the acyl remodeling of phospholipids [83]. Cell cytotoxic effects through activation of $\mathrm{PLA}_{2}$ by melittin have been suggested to be critical mechanism for anti-cancer activity of bee venom. Apoptotic cell death induction through several cancer cell death mechanisms, including activation of caspase and matrix metalloproteinases, is important for melittin-induced anti-cancer effects [84]. Loss of $\mathrm{cPLA}_{2}$ activity, either through genetic knockout in mice, or by treatment with a $\mathrm{PLA}_{2}$ inhibitor, results in an attenuation of arachidonic acid release as well as of the apoptotic response to oxLDL in peritoneal macrophages or to $25-\mathrm{OHC}$ in cultured fibroblast and macrophage cell lines [85].

We showed that effect of secreted patatin on tumour cells mainly proceeds by apoptosis. Necrosis would process through production of lysophospholipids, which can decrease resistance of cell membrane. Lysophospholipids, lysoPA, are lipid mediators that are involved in wide variety of biological responses in animals. Recently, IIA PLA 2 protein content was shown dramatically decreased in malignant colorectal tumours as compared with adenomas. The protein was also found in apoptotic cells, necrosis, peritumoural mucosa and in invasive front of carcinomas [86].

Drugs targeted cancer cell membrane might become a new and high effective clinical cancer therapy. One is to use phospholipase $\mathrm{A}_{2}\left(\mathrm{PLA}_{2}\right)$ to cleave phospholipid heads of the bilayer of cancer cells [73]. Degradative action of LAH may alter capacity of lipid bilayer to regulate exchanges between compartments, but many subsequent physiological responses are due to novel biological properties of lysolipids or oxygenated fatty acid derivatives that are generated [87]. Arabidopsis Patatin-Like Protein 2 (PLP2) plays an essential role in cell death execution and differentially affects biosynthesis of oxylipins and resistance to pathogens. PLP2 is an integral component of the plant cell death execution machinery, possibly providing fatty acid precursors for the biosynthesis of specific oxylipins and differentially affecting resistance to pathogens with distinct lifestyles [22].

Among the large family of PLA ${ }_{2}$ enzymes, calciumindependent phospholipases A2 ( $\left.\mathrm{PLLA}_{2}\right)$ represent a relatively novel subgroup. The fact that $\mathrm{iPLA}_{2}$ have been recently described as key mediators for proliferation of cancer cells, such as colon cancer, ovarian cancer or prostate cancer cells, emphasizes their potential role as molecular targets for cancer treatment $[88,89]$. Functional role of $\mathrm{iPLA}_{2}$ in prostate cancer has been mainly demonstrated in vitro. Recently, down-regulation of $\mathrm{iPLA}_{2}-\beta$ in prostate tumor cells has been correlated with reduced tumorigenesis and metastasis in vivo $[90,91]$.

A model for specific activity of secreted patatin (e-patatin) on tumour cells can be proposed (Figure 8). We suggest that PLA $_{2}$-like enzyme (e-patatin), which can be obtained from secretion of potato tubers triggered by a physical stress, recognizes and mainly binds anionic phospholipids PS or PE, localized on external leaflet of tumour cell membrane. Subsequently, arachidonic acid, in animal cells, or linonenic acid, in plant cells, is released which, in turn, induces apoptotic pathway or may trigger necrosis. Then, enhanced free PUFA would increase the activity of PLA $_{2}$ enzyme, as it was previously described for activation of $\mathrm{sPLA}_{2}$ [92]. We have also observed that mixture of linoleic acid and purified e-patatin showed higher cytotoxic effect on crown-gall cells than e-patatin alone; at this concentration, linoleic acid alone has no effect on plant tumour cells.

Previously, we have shown that wound-desiccation stress on various storage plant tissues allowed secretion of products that had specific cytotoxicity against melanoma B16 cells. Healthy plant or animal cells were not susceptible to these products. Secretion of active product varied with plant species and plant organs. Secretion products of tubers of yam (Dioscorea cayenensis Lam), cassava (Manihot esculenta), Jerusalem artichoke (Helianthus tuberosus), ginger (Zingiber officinale) and potato (Solanum tuberosum L.) showed activity against murine melanoma B16 cells, but not against immortalized fibroblast L929 cells. Active agent was associated with a protein complex. Secretion of cytotoxic products against melanoma B16 cells, thus, can be performed through specific stress on storage organs of plants usually cultivated [93]. In Jerusalem artichoke (Helianthus tuberosus L.) tubers, active agent was shown to contain 18-kDa polypeptide with homology to superoxide dismutase (SOD) [2].

\section{CONCLUSION}

In summary, these findings support a model put forward in Figure 8 where $\mathrm{PLA}_{2}$-patatin reveals as a protein with a multifunctional role. Therefore, a double stress of potato tubers induces secretion of a patatin-like protein that displays an unusual iPLA $\mathrm{P}_{2}$ enzyme activity, which is required for its specific activity against B16 tumour cells. The prevention and therapy of cancer may benefit from the introduction of new treatments derived from natural products. Many pharmaceutical products approved for 


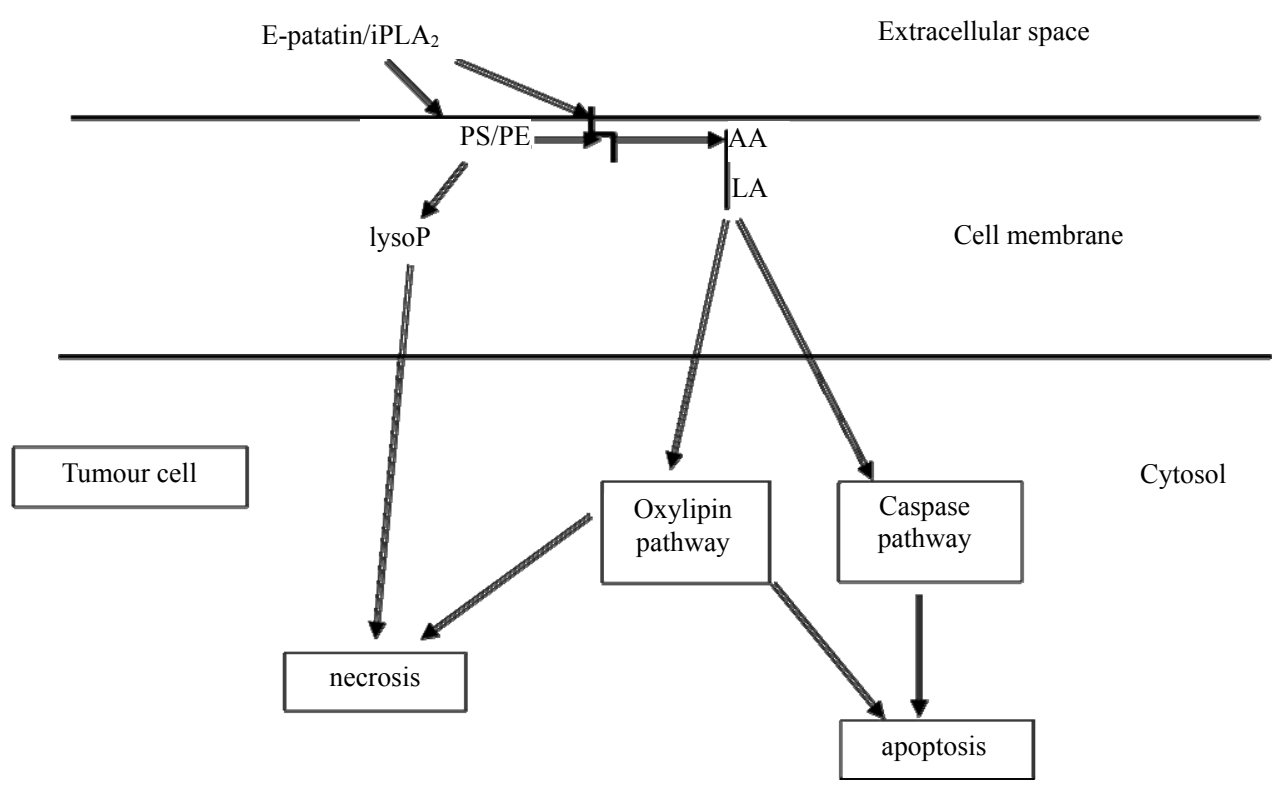

Figure 8. Model for secretion product, e-patatin, effect against tumour cells. Lipid messengers derived from hydrolysis of plasma membrane [94]. AA: arachidonic acid; LA: linoleic acid; LysoP: lysophospholipids. PE: phosphatidylethanolamine; PS: phosphatidylserine; Arrows indicate flow of signalling pathway. Secreted e-patatin/iPLA 2 , from safe plant cells, directly acts on outer leaflet of tumour cell membrane to release fatty acids (including arachidonic acid or linolenic acid) and lysophospholipids, both of which can activate signal transduction pathway (apoptosis), by increasing $\mathrm{Ca}^{2+}$ concentration. Eventually, a pathway triggering the weakness of the cell membrane (necrosis) can be developed.

human disease treatment are derived from natural sources [95]. This patatin-like $\mathrm{PLA}_{2}$ thus repre- sents a new member of the lipolytic superfamily and could represent a novel therapeutic product for the de- velopment of new anticancer agents.

\section{ACKNOWLEDGEMENTS}

This research was supported by grants from ANVAR ( $\mathrm{n}^{\circ}$ A9907080C/ AT) and ARC. We are grateful to Pr. M. Andréani, Dr. N. Uhrhammer, Dr. J. C. Maurizis for their skilful advices, to R. Cochet, N. Roussel, G. Evray, D. Marcon, and C. Vian for their skilful technical assistance.

\section{REFERENCES}

[1] Griffaut, B., Bos, R., Maurizis, J.C., Madelmont, J.C. and Ledoigt, G. (2004) Cytotoxic effects of kinetin riboside on mouse, human and plant tumour cells. International Journal of Biological Macromolecules, 34, 271-275. http://dx.doi.org/10.1016/j.ijbiomac.2004.06.004

[2] Griffaut, B., Debiton, E., Madelmont, J.C., Maurizis, J.C. and Ledoigt, G. (2007) Stressed Jerusalem artichoke tubers (Helianthus tuberosus L.) excrete a protein fraction with specific cytotoxicity on plant and animal tumour cell. Biochimica Biophyica. Acta-General Subjects, 1770, 1324-1330.

[3] Ledoigt, G., Griffaut, B., Debiton, E., Vian, C., Mustel, A., Evray, G., Maurizis, J.C. and Madelmont, J.C. (2006)
Analysis of secreted protease inhibitors after water stress in potato tubers. International Journal of Biological Macromolecules, 38, 268-271. http://dx.doi.org/10.1016/j.ijbiomac.2006.03.016

[4] Scherer, G.F.E., Ryu, S.B., Wang, X., Matos, A.R. and Heitz, T. (2010) Patatin-related phospholipase A: nomenclature, subfamilies and functions in plants. Trends in Plant Science, 15, 693-700. http://dx.doi.org/10.1016/j.tplants.2010.09.005

[5] Bárta, J., Bártová, V., Zdráhal, Z. and Šedo, O. (2012) Cultivar Variability of Patatin Biochemical Characteristics: Table versus Processing Potatoes (Solanum tuberosum L.). Journal of Agricultural and Food Chemistry, 60, 4369-4378. http://dx.doi.org/10.1021/jf3003448

[6] Bauw, G., Nielsen, H.V., Emmersen, J., Nielsen, K.L., Jørgensen, M. and Welinder, K.G. (2006) Patatins, Kunitz protease inhibitors and other major proteins in tuber of potato cv. Kuras. FEBS Journal, 273, 3569-3584. http://dx.doi.org/10.1111/j.1742-4658.2006.05364.x

[7] Lehesranta, S.J., Davies, H.V., Shepherd, L.V., Koistinen, K.M., Massat, N., Nunan, N., McNicol, J.W. and Kärenlampi, S.O. (2006) Proteomic analysis of the potato tuber life cycle. Proteomics, 6, 6042-6052. http://dx.doi.org/10.1002/pmic.200600383

[8] Bevan, M., Barker, R., Goldsbrough, A., Jarvis, M., Kavanagh, T. and Iturriaga, G. (1986) The structure and transcription start site of a major potato tuber protein gene. Nucleic Acids Research, 14, 4625-4638. http://dx.doi.org/10.1093/nar/14.11.4625 
[9] Rosahl, S., Schmidt, R., Schell, J. and Willmitzer, L., (1986) Isolation and characterization of a gene from Solanum tuberosum encoding patatin, the major storage protein of potato tubers. Molecular and General Genetics, 203, 214-220. http://dx.doi.org/10.1007/BF00333957

[10] Pots, A.M., Gruppen, H., Hessing, M., van Boekel, M.A. and Voragen, A.G. (1999) Isolation and characterization of patatin isoforms. Journal of Agricultural and Food Chemistry, 47, 4587-4592. http://dx.doi.org/10.1021/jf981180n

[11] Mignery, G.A., Pikaard, C.S. and Park, W.D. (1988) Molecular characterization of the patatin multigene family of potato. Gene, 62, 27-44. http://dx.doi.org/10.1016/0378-1119(88)90577-X

[12] Twell, D. and Ooms, G. (1988) Structural diversity of the patatin gene family in potato cv. Desiree. Molecular and General Genetics, 212, 325-336. http://dx.doi.org/10.1007/BF00334703

[13] Senda, K., Yoshioka, H., Doke, N. and Kawakita, K.A. (1996) A cytosolic phospholipase $A_{2}$ from potato tissues appears to be patatin. Plant and Cell Physiology, 37, 347353. http://dx.doi.org/10.1093/oxfordjournals.pcp.a028952

[14] Rydel, T.J., Williams, J.M., Krieger, E., Moshiri, F., Stallings, W.C., Brown, S.M., Pershing, J.C., Purcell, J.P. and Alibhai, M.F. (2003) The crystal structure, mutagenesis, and activity studies reveal that patatin is a lipid acyl hydrolase with a Ser-Asp catalytic dyad. Biochemistry, 42, 6696-6708.

[15] Andrews, D.L., Beames, B., Summers, M.D. and Park, W.D. (1988) Characterization of the lipid acyl hydrolase activity of the major potato (Solanum tuberosum) tuber protein, patatin, by cloning and abundant expression in a baculovirus vector. Biochemical Journal, 252, 199-206.

[16] Balsinde, J. and Dennis, E.A. (1997) Function and inhibition of intracellular calcium-independent phospholipase $\mathrm{A}_{2}$. Journal of Biological Chemistry, 272, 16069-16072. http://dx.doi.org/10.1074/jbc.272.26.16069

[17] Six, D.A. and Dennis, E.A. (2000) The expanding superfamily of phospholipase A(2) enzymes: Classification and characterization. Biochimica et Biophysica Acta-Molecular and Cell Biology of Lipids, 1488, 1-19.

[18] Murakami, M. and Kudo, I. (2004) Diversity of Phospholipase $\mathrm{A}_{2}$ enzymes. Secretory phospholipase $\mathrm{A}_{2}$. Biological and Pharmaceutical Bulletin, 27, 1158-1164. http://dx.doi.org/10.1248/bpb.27.1158

[19] Ryu, S.B. (2004) Phospholipid-derived signalling mediated by phospholipase A in plants. Trends in Plant Science, 9, 229-235. http://dx.doi.org/10.1016/j.tplants.2004.03.004

[20] Wilson, P.A., Gardner, S.D., Lambie, N.M., Commans, S.A. and Crowther, D.J. (2006) Characterization of the human patatin-like phospholipase family. Journal of Lipid Research, 47, 1940-1949. http://dx.doi.org/10.1194/jlr.M600185-JLR200

[21] Wang, X. (2001) Plant Phospholipases. Annual Review of Plant Physiology and Plant Molecular Biology, 52, 211231. http://dx.doi.org/10.1146/annurev.arplant.52.1.211

[22] La Camera, S., Balagué, C., Göbel, C., Geoffroy, P., Le- grand, M., Feussner, I., Roby, D. and Heitz, T. (2009) The Arabidopsis Patatin-Like Protein 2 (PLP2) plays an essential role in cell death execution and differentially affects biosynthesis of oxylipins and resistance to pathogens. Molecular Plant-Microbe Interactions, 22, 469-481. http://dx.doi.org/10.1094/MPMI-22-4-0469

[23] Wang, X., Huang, C-J., Yu, G-Z., Wang, J-J., Wang, R., $\mathrm{Li}, \mathrm{Y}-\mathrm{M}$. and $\mathrm{Wu}, \mathrm{Q}$. (2013) Expression of group IIA phospholipase A2 is an independent predictor of favorable outcome for patients with gastric cancer. Human Pathology, 44, 2047-2054.

http://dx.doi.org/10.1016/j.humpath.2013.03.009

[24] Griffaut, B., Smit, C. and Ledoigt, G. (1994) Evidence for in vitro interactions between bud and parenchyma in Jerusalem artichoke tubers during breaking of dormancy promoted by two $\mathrm{N}$-acetylhexosamines. Effect on membrane lectin localization. Plant Physiology and Biochemistry, 32, 437-442.

[25] Bradford, M.M. (1976) A rapid and sensitive method for the quantitation of microgram quantities of protein utilizing the principle of protein-dying binding. Analytical Biochemistry, 72, 248-254.

http://dx.doi.org/10.1016/0003-2697(76)90527-3

[26] Clarke, A.K. and Critchley, C. (1992) The identification of a heat-shock protein complex in chloroplasts of barley leaves. Plant Physiology, 100, 2081-2089.

http://dx.doi.org/10.1104/pp.100.4.2081

[27] Laemmli, U.K. (1987) Cleavage of structural proteins during the assembly of the head of bacteriophage T4. Nature, 227, 680-685. http://dx.doi.org/10.1038/227680a0

[28] Schagger, H. and Von Jagow, H. (1987) Tricine-sodium dodecyl sulfate-polyacrylamide gel electrophoresis for the separation of proteins in the range from 1 to $100 \mathrm{kDa}$. Analytical Biochemistry, 166, 368-379. http://dx.doi.org/10.1016/0003-2697(87)90587-2

[29] Blum, H., Beier, H. and Gross, H.J. (1987) Improved silver staining of plant proteins, RNA and DNA in polyacrylamide gels. Electrophoresis, 8, 93-99. http://dx.doi.org/10.1002/elps.1150080203

[30] Irie, S., Sesaki, M. and Kato, Y. (1982) A faithful double stain of proteins in the polyacrylamide gels with Coomassie blue and silver. Analytical Biochemistry, 126, 350-354. http://dx.doi.org/10.1016/0003-2697(82)90526-7

[31] O'Farrell, P.H. (1975) High resolution two-dimensional electrophoresis of proteins. Journal of Biological Chemistry, 250, 4007-4021.

[32] Edman, P. and Begg, G. (1967) A protein sequenator. European Journal of Biochemistry, 1, 80-91. http://dx.doi.org/10.1111/j.1432-1033.1967.tb00047.x

[33] Radvanyi, F., Jordan, L., Russo-Marie, F. and Bon, C. (1989) A sensitive and continuous fluorometric assay for phospholipase A2 using pyrene-labeled phospholipids in the presence of serum albumin. Analytical Biochemistry, 177, 103-109. http://dx.doi.org/10.1016/0003-2697(89)90022-5

[34] Jenkins, C.M., Han, X., Mancuso, D.J. and Gross, R.W. (2002) Identification of calcium-independent Phospholi- 
pase $\mathrm{A}_{2}\left(\mathrm{iPLA}_{2}\right) \beta$, and Not iPLA 2 , as the mediator of arginine vasopressin-induced arachidonic acid release in A-10 smooth muscle cells. Journal of Biological Chemistry, 277, 32807-32814.

http://dx.doi.org/10.1074/jbc.M202568200

[35] Swarup, G., Cohen, S. and Garbers, D.L. (1982) Inhibition of membrane phosphotyrosyl-protein phosphatase activity by vanadate. Biochemical and Biophysical Research Communication, 107, 1104-1109.

http://dx.doi.org/10.1016/0006-291X(82)90635-0

[36] Otani, M., Shitan, N., Sakai, K., Martinoia, E., Sato, F. and Yazaki, K. (2005) Characterization of vacuolar transport of the endogenous alkaloid berberine in Coptis japonica. Plant Physiology, 138, 1939-1946. http://dx.doi.org/10.1104/pp.105.064352

[37] May, C., Preisig-Müller, R., Höhne, M., Gnau, P. and Kindl, H. (1998) A phospholipase $A_{2}$ is transiently synthesized during seed germination and localized to lipid bodies. Biochimica et Biophysica ActaLipids and Lipid Metabolism, 1393, 267-276.

[38] Valueva, T.A., Revina, T.A., Gvozdeva, E.L., Gerasimova, N.G., Il'inskaia, L.I. and Ozeretskovakaia, O.L. (2001) Effects of elicitors on accumulation of protease inhibitors in injured potato tubers. Prikladnaia Biohimiia I Mikrobiologiia, 37, 601-606.

[39] Mancuso, D.J., Jenkins, C.M., Gross, R.W. (2000) The genomic organization, complete mRNA sequence, cloning, and expression of a novel human intracellular membrane-associated calcium-independent phospholipase $\mathrm{A}_{2}$. Journal of Biological Chemistry, 275, 9937-9945. http://dx.doi.org/10.1074/jbc.275.14.9937

[40] Holk, A., Rietz, S., Zahn, M., Quader, H. and Scherer, G.F.E. (2002) Molecular identification of cytosolic, patatin-related phospholipases a from Arabidopsis with potential functions in plant signal transduction. Plant Physiology, 130, 90-101. http://dx.doi.org/10.1104/pp.006288

[41] Baji, M., M'Hamdi, M., Gastiny, F., Deleplace, P., Fauconnier, M.L. and Du Jardin, P. (2007) Catalase inhibittion alters suberization and wound healing in potato (Solanum tuberosum) tubers. Physiologia Plantarum, 129, 472-483.

http://dx.doi.org/10.1111/j.1399-3054.2006.00844.x

[42] Jung, K.M. and Kim, D.K. (2000) Purification and characterization of a membrane-associated 48-kilodalton phospholipase $\mathrm{A}_{2}$ in leaves of broad bean. Plant Physiology, 123, 1057-1067.

http://dx.doi.org/10.1104/pp.123.3.1057

[43] Reina-Pinto, J.J., Voisin, D., Kurdyukov, S., Faust, A., Haslam, R.P., Michaelson, L.V., Efremova, N., Franke, B., Schreiber, L., Napier, J.A. and Yephremov, A. (2009) Misexpression of fatty acid elongation1 in the Arabidopsis epidermis induces cell death and suggests a critical role for phospholipase $\mathrm{A}_{2}$ in this process. Plant Cell, 21, 1252-1572. http://dx.doi.org/10.1105/tpc.109.065565

[44] Ferguson, E.I., Richardson, S.C.W. and Duncan, R. (2010) Studies on the mechanism of action of dextrin-phospholipase $\mathrm{A}_{2}$ and its suitability for use in combination therapy. Molecular Pharmaceutics, 7, 510-521.

\section{http://dx.doi.org/10.1021/mp900232a}

[45] Donato, N.J., Martin, C.A., Perez, M., Newman, R.A., Vidal, J.C. and Etcheverry, M. (1996) Regulation of epidermal growth factor receptor activity by crotoxin, a snake venom phospholipase $\mathrm{A}_{2}$ toxin. A novel growth inhibitory mechanism. Biochemical Pharmacology, 51, 1535-1543. http://dx.doi.org/10.1016/0006-2952(96)00097-4

[46] Zhao, S., Du, X.Y., Chen, J.S., Zhou, Y.C. and Song, J.G. (2002) Secretory phospholipase $A_{2}$ inhibits epidermal growth factor-induced receptor activation. Experimental Cell Research, 279, 354-364. http://dx.doi.org/10.1006/excr.2002.5622

[47] Cura, J.E., Blanzaco, D.P., Brisson, C., Cura, M.A., Cabrol, R., Larrateguy, L., Mendez, C., Sechi, J.C., Silveira, J.S., Theiller, E., de Roodt, A.R. and Vidal, J.C. (2002) Phase I and pharmacokinetics study of crotoxin (cytotoxic PLA2, NSC-624244) in patients with advanced cancer. Clinical Cancer Research, 8, 1033-1041.

[48] Lei, X., Barbour, S.E. and Ramanadham, S. (2010) Group VIA Ca ${ }^{2+}$-independent phospholipase $\mathrm{A}_{2}\left(\mathrm{iPLA}_{2} \beta\right)$ and its role in $\beta$-cell programmed cell death. Biochimie, 92, 627637. http://dx.doi.org/10.1016/j.biochi.2010.01.005

[49] Song, H., Wohltmann, M., Tan, M., Bao, S., Ladenson, J.H. and Turk, J. (2012) Group VIA PLA $2\left(\right.$ iPLA $\left._{2} \beta\right)$ is activated upstream of $\mathrm{p} 38$ mitogen-activated protein kinase (MAPK) in pancreatic islet $\beta$-cell signaling. Journal of Biological Chemistry, 287, 5528-5541. http://dx.doi.org/10.1074/jbc.M111.285114

[50] Murakami, T., Kamikado, N., Fujimoto, R., Hamaguchi, K., Nakamura, H., Chijiwa, T., Ohno, M. and Oda-Ueda, N. (2011) A $\left[\mathrm{Lys}^{49}\right]$ phospholipase $\mathrm{A}_{2}$ from protobothrops flavoviridis venom induces caspase-independent apoptotic cell death accompanied by rapid plasma-membrane rupture in human leukemia cells. Bioscience Biotechnology \& Biochemistry, 75, 864-870. http://dx.doi.org/10.1271/bbb.100783

[51] Samel, M., Vija, H., Kurvet, I., Künnis-Beres, K., Trummal, K., Subbi, J., Kahru, A. and Siigur, J. (2013) Interactions of $\mathrm{PLA}_{2}$-s from Vipera lebetina, Vipera berus berus and Naja naja oxiana venom with platelets, bacterial and cancer cells. Toxins, 24, 203-223. http://dx.doi.org/10.3390/toxins5020203

[52] Notari, L., Baladron, V., Aroca-Aguilar, J.D., Balko, N., Meyer, C., Notario, P.M., Saravanamuthu, S., Nueda, M.L., Sanchez-Sanchez, F., Escribano, J., Laborda, J. and Becerra, S.P. (2001) Identification of a lipase-linked cell membrane receptor for pigment epithelium-derived factor. Journal of Biological Chemistry, 281, 38022-38037. http://dx.doi.org/10.1074/jbc.M600353200

[53] Hirsch, J., Johnson, C.L., Nelius, T., Kennedy, R., de Riese, W. and Filleur, S. (2011) PEDF inhibits IL8 production in prostate cancer cells through PEDF receptor/ phospholipase $\mathrm{A}_{2}$ and regulation of $\mathrm{NF} \kappa \mathrm{B}$ and $\operatorname{PPAR} \gamma$. Cytokine, 55, 202-210. http://dx.doi.org/10.1016/j.cyto.2011.04.010

[54] Atsumi, G., Tajima, M., Hadano, A., Nakatani, Y., Murakami, M. and Kudo, I. (1998) Fas-induced arachidonic acid release mediated by $\mathrm{Ca}^{2+}$-independent phospholipase 
$\mathrm{A}_{2}$ but not cytosolic phospholipase $\mathrm{A}_{2}$, which undergoes proteolytic inactivation. Journal of Biological Chemistry, 273, 13870-13877. http://dx.doi.org/10.1074/jbc.273.22.13870

[55] Kronke, M. and Adam-Klages, S. (2002) Role of caspases in TNF-mediated regulation of $\mathrm{cPLA}_{2}$. FEBS Letters, 531, 18-22.

http://dx.doi.org/10.1016/S0014-5793(02)03407-5

[56] Dong, M., Johnson, M., Rezaie, A.I., Ilsley, J.N., Nakanishi, M., Sanders, M.M., Forouhar, F., Levine, J., Montrose, D.C., Giardina, C. and Rosenberg, D.W. (2007) Cytoplasmic phosphorylase $\mathrm{A}_{2}$ levels correlate with apoptosis in human colon tumorigenesis. Clinical Cancer Research, 11, 2265-2271.

http://dx.doi.org/10.1158/1078-0432.CCR-04-1079

[57] Peterson, B., Knotts, T. and Cummings, B.S. (2007) Involvement of $\mathrm{Ca}^{2+}$-independent phospholipase $\mathrm{A}_{2}$ isoforms in oxidant-induced neural cell death. Neuro Toxicology, 28, 150-160.

http://dx.doi.org/10.1016/j.neuro.2006.09.006

[58] Zhang, L., Peterson, B.L. and Cummings, B.S. (2005) The effect of inhibition of $\mathrm{Ca}^{2+}$-independent phospholipase $\mathrm{A}_{2}$ on chemotherapeutic-induced death and phospholipids profile renal cells. Biochemical Pharmacology, 70, 1697-1706.

http://dx.doi.org/10.1016/j.bcp.2005.09.008

[59] Vento, R., D’Alessandro, N., Giuliano, M., Lauricella, M. Carabillo, M. and Tesoriere, G. (2000) Induction of apoptosis by arachidonic Acid in human retinoblastoma Y79 cells: Involvement of oxidative stress. Experimental Eye Research, 70, 503-517. http://dx.doi.org/10.1006/exer.1998.0810

[60] Cupillard, L., Mulherkar, R., Gomez, N., Kadam, S., Valentin, E., Lazdunski, M. and Lambeau, G. (1999) Both group $1 \mathrm{~B}$ and group IIA secreted phospholipases $\mathrm{A}_{2}$ are natural ligands of the mouse $180-\mathrm{kDa}$ M-type receptor. Journal of Biological Chemistry, 274, 7043-7051. http://dx.doi.org/10.1074/jbc.274.11.7043

[61] Belinsky, G.S., Rajan, T.V., Saria, E.A., Giardina, C. and Rosenberg, D.W. (2007) Expression of secretory phospholipase $\mathrm{A}_{2}$ in colon tumor cells potentiates tumor growth. Molecular Carcinogenesis, 46, 106-116. http://dx.doi.org/10.1002/mc.20271

[62] Utsugi, T., Schroit, A., Connor, J., Bucana, C. and Fidler, I. (1991) Elevated expression of phosphatidylserine in the outer leaflet of human tumor cells and recognition by activated human blood monocytes. Cancer Research, 51, 3062-3066.

[63] De Jong, K., Rettig, M.P., Low, P.S. and Kuypers, F.A. (2002) Protein kinase $C$ activation induces phosphatedylserine exposure on red blood cells. Biochemistry, 41, 12562-12567. http://dx.doi.org/10.1021/bi0258820

[64] Burlakova, E.B., Molochkina, E.M. and Pal'mina, N.P. (1980) Role of membrane lipid oxidation in control of enzymatic activity in normal and cancer cells. Advances in Enzyme Regulation, 18, 163-179. http://dx.doi.org/10.1016/0065-2571(80)90014-X

[65] Zachowski, A. (1993) Phospholipids in animal eukaryotic membranes: Transverse asymmetry and movement. Bio- chemical Journal, 294, 1-14.

[66] Wang, X. (2004) Lipid signalling. Current Opinion in Plant Biology, 7, 329-336. http://dx.doi.org/10.1016/j.pbi.2004.03.012

[67] Wee, C.L., Balali-Mood, K., Gavaghan, D. and Sansom, M.S.P. (2008) The interaction of phospholipase $A_{2}$ with a phospholipid bilayer: Coarse-grained molecular dynamics simulations. Biophysical Journal, 95, 1649-1657. http://dx.doi.org/10.1529/biophysj.107.123190

[68] Wu,Y., Raymond, B., Goossens, P.L., Njamkepo, E., Guiso, N., Paya, M. and Touqui, L. (2010) Type-IIA secreted phospholipase $A_{2}$ is an endogenous antibiotic-like protein of the host. Biochimie, 92, 583-587. http://dx.doi.org/10.1016/j.biochi.2010.01.024

[69] Pilane, C.M. and LaBelle, E.F. (2002) Arachidonic acid release by cPLA $_{2}$ may be causally related to NO-induced apoptosis in vascular smooth muscle cells. Journal of Cellular Physiology, 191,191-197. http://dx.doi.org/10.1002/jep.10090

[70] Pilane, C.M. and Labelle, E.F. (2004) cPLA $_{2}$ activator peptide, PLAP, increases arachidonic acid release and apoptosis of vascular smooth muscle cells. Journal of Cellular Physiology, 198, 48-52. http://dx.doi.org/10.1002/jcp.10382

[71] Björnsdottir, H., Granfeldt, D., Welin, A., Bylund, J. and Karlsson, A. (2013) Inhibition of phospholipase $A_{2}$ abrogates intracellular processing of NADPH-oxidase derived reactive oxygen species inhuman neutrophils. Experimental Cell Research, 319, 761-774.

http://dx.doi.org/10.1016/j.yexcr.2012.12.020

[72] Cao, Y., Pearman, A.T., Zimmerman, G.A., McIntyre, T.M. and Prescott, S.M. (2000) Intracellular unesterified arachidonic acid signals apoptosis. Proceedings of the National Academy of Sciences the United States of America, 97, 11280-11285. http://dx.doi.org/10.1073/pnas.200367597

[73] Feng, Y., Wang, B., Cao, Y. and He, R. (2013) Two novel approaches targeting cancer cell membrane for tumor therapy. Medical Hypotheses, 80, 380-382. http://dx.doi.org/10.1016/j.mehy.2012.12.025

[74] Scott, K.F., Sajinovic, M., Hein, J., Nixdorf, S., Galettis, P., Liauw, W., de Souza, P., Dong, Q., Graham, G.G. and Russell, P.J. (2010) Emerging roles for phospholipase $A_{2}$ enzymes in cancer. Biochimie, 92, 601-610. http://dx.doi.org/10.1016/j.biochi.2010.03.019

[75] Surette, M.E., Winkler, J.D., Fonteh, A.N. and Floyd, H. (1996) Chilton relationship between arachidonate-Phospholipid remodeling and apoptosis. Biochemistry, 35, 9187-9196. http://dx.doi.org/10.1021/bi9530245

[76] Pecker, F., Amadou, A., Magne, S. and Pavoine, C. (1998) The messenger role of arachidonic acid in cardiomyocytes. Médecine/Sciences, 14, 1009-1016. http://dx.doi.org/10.4267/10608/905

[77] Penzo, D., Petronilli, V., Angelin, A., Cusan, C., Colonna, R., Scorrano, L., Pagano, F., Prato, M., Di Lisa, F. and Bernardi, P. (2004) Arachidonic acid released by phospholipase $\mathrm{A}_{2}$ activation triggers $\mathrm{Ca}^{2+}$-dependent apoptosis through the mitochondrial pathway. Journal of Biological 
Chemistry, 279, 25219-25225. http://dx.doi.org/10.1074/jbc.M310381200

[78] Liou, J.-Y., Aleksic, N., Chen, S.-F., Han, T.-J., Shyue, S.-K. and Wu, T.K.K. (2005) Mitochondrial localization of cyclooxygenase-2 and calcium-independent phospholipase $\mathrm{A}_{2}$ in human cancer cells: Implication in apoptosis resistance. Experimental Cell Research, 306, 75-84. http://dx.doi.org/10.1016/i.yexcr.2005.01.011

[79] Burke, J.E. and Dennis, E.A. (2009) Phospholipase $\mathrm{A}_{2}$ biochemistry. Cardiovascular Drugs Therapy, 23, 49-59. http://dx.doi.org/10.1007/s10557-008-6132-9

[80] Burke, J.E. and Dennis, E.A. (2009) Phospholipase $\mathrm{A}_{2}$ structure/function, mechanism, and signaling. Journal of Lipid Research, 50, S237-S242. http://dx.doi.org/10.1194/jlr.R800033-JLR200

[81] Cai, H., Chiorean, E.G., Chiorean, M.V., Rex, D.K., Robb, B.W., Hahn, N.M., Liu, Z., Loehrer, P.J., Harrison, M.L. and $\mathrm{Xu}, \mathrm{Y}$. (2013) Elevated phospholipase $\mathrm{A}_{2}$ activities in plasma samples from multiple cancers. PLoS One, 8.

http://dx.doi.org/10.1371/journal.pone.0057081

[82] Chen, K.C. and Chang, L.S. (2009) Arachidonic acid-induced apoptosis of human neuroblastoma SK-N-SH cells is mediated through mitochondrial alteration elicited by ROS and $\mathrm{Ca}^{2+}$-evoked activation of p38 $\alpha$ MAPK and JNK1. Toxicology, 262, 199-206.

http://dx.doi.org/10.1016/j.tox.2009.06.009

[83] Reina-Pinto, J.J. and Yephremov, A. (2009) Lipid determinants of cell death. Plant Signaling \& Behavior, 4, 625-628. http://dx.doi.org/10.4161/psb.4.7.8923

[84] Oršolić, N. (2012) Bee venom in cancer therapy. Cancer and Metastasis Reviews, 31, 173-194.

http://dx.doi.org/10.1007/s10555-011-9339-3

[85] Panini, S.R., Yang, L., Rusinol, A.E., Sinensky, M.S., Bonventre, J.V. and Leslie, C.C. (2001) Arachidonate metabolism and the signaling pathway of induction of apoptosis by oxidized LDL/oxysterol. Journal of Lipid Research, 42, 1678-1686.

[86] Avoranta, T., Sundström, J., Korkeila, E., Syrjänen, K., Pyrhönen, S. and Lain, J. (2010) The expression and distribution of group IIA phospholipase $\mathrm{A}_{2}$ in human colorectal tumours. Virchows Archiv, 457, 659-667.

\footnotetext{
ABBREVIATIONS

$\mathrm{AA}=$ arachidonic acid

ATK $=$ Arachidonyl trifluoromethyl ketone

$\mathrm{BEL}=$ bromoenol lactone, E)-6-(bromomethylene)-3-

(1-naphtalenyl)2H-tetrahydropyran-2-one

$\mathrm{cPLA}_{2}=$ cytosolic phospholipase $\mathrm{A}_{2}$

2D IEF $=$ Two-dimension isoelectric focusing

DMSO $=$ dimethylsulfoxide

2D PAGE = Two-dimension Polyacrylamide Gel Electrophoresis

$\mathrm{iPLA}_{2}=$ calcium-independent phospholipase $\mathrm{A}_{2}$

MAFP $=$ methyl arachidonyl fluoromethyl phosphonate
}

http://dx.doi.org/10.1007/s00428-010-0992-7

[87] Grienenberger, E., Geoffroy, P., Mutterer, J., Legrand, M. and Heitz, T. (2010) The interplay of lipid acyl hydrolases in inducible plant defense. Plant Signaling \& Behavior, 5, 1181-1186. http://dx.doi.org/10.4161/psb.5.10.12800

[88] Scott, K.F., Sajinovic, M., Hein, J., Nixdorf, S., Galettis, P., Liauw, W., de Souza, P., Dong, Q., Graham, G.G. and Russell, P.J. (2010) Emerging roles for phospholipase $A_{2}$ enzymes in cancer. Biochimie, 92, 601-610. http://dx.doi.org/10.1016/j.biochi.2010.03.019

[89] Li, H., Zhao, Z., Wei, G., Yan, L., Wang, D., Zhang, H., Sandusky, G.E., Turk, J. and Xu, Y. (2010) Group VIA phospholipase $\mathrm{A}_{2}$ in both host and tumor cells is involved in ovarian cancer development. The FASEB Journal, 24, 4103-4116. http://dx.doi.org/10.1096/fj.10-161356

[90] Hui, K., Li, H.Z., Wei, G., Cai, Q., Yan, L. and Xu, Y. (2011) Tumor cell group VIA phospholipase $A_{2}$ is involved in prostate cancer development. The Prostate, 71, 373-384. http://dx.doi.org/10.1002/pros.21251

[91] Hirsch, J., Johnson, C.L., Nelius, T., Kennedy, R., Riese, W.D. and Filleur, S. (2011) PEDF inhibits IL8 production in prostate cancer cells through PEDF receptor/phospholipase $\mathrm{A}_{2}$ and regulation of $\mathrm{NF} \kappa \mathrm{B}$ and $\mathrm{PPAR} \gamma$. Cytokine, 55, 202-210. http://dx.doi.org/10.1016/i.cyto.2011.04.010

[92] Kambe, T., Murakami, M. and Kudo, I. (1999) Polyunsaturated fatty acids potentiate interleukin-1-stimulated arachidonic acid release by cells overexpressing type IIA secretory phospholipase $\mathrm{A}_{2}$. FEBS Letters, 453, 81-84. http://dx.doi.org/10.1016/S0014-5793(99)00702-4

[93] Ledoigt, G., Chevalier, K., Debiton, E. and Griffaut, B. (2009) Secretion of specific cytotoxic products by plant storage organs after wound-desiccation stress. Plant Stress, 3, 26-32.

[94] Zhao, J., Davis, L.C. and Verpoorte, R. (2005) Elicitor signal transduction leading to production of plant seconddary metabolites. Biotechnology Advances, 23, 283-333. http://dx.doi.org/10.1016/j.biotechadv.2005.01.003

[95] Thornthwaite, J.T., Shah, H.R., Shah, P., Peeples, W.C. and Respess, H. (2013) The formulation for cancerprevention \& therapy. Advances in Biological Chemistry, 3, 356-387.

$\mathrm{MW}=$ molecular weight

$\mathrm{PC}=$ phosphatidylcholine

$\mathrm{PE}=$ phosphatidylethanolamine

$\mathrm{PLA}_{2}=$ phospholipase $\mathrm{A}_{2}$

$\mathrm{PR}=$ Pathogenesis-Related

$\mathrm{PS}=$ phosphatidylserine

PTK = Palmitoyl trifluorylmethyl ketone

PUFA $=$ Polyunsaturated Fatty Acid

SDS PAGE $=$ Sodium Dodecyl Sulphate Polyacrylamide Gel Electrophoresis

$\mathrm{SM}=$ sphingomyeline

$\mathrm{SPLA}_{2}=$ secreted $\mathrm{PLA}_{2}$ 